\title{
Occurrence of Fe-Mg-rich smectites and corrensite in the Morrón de Mateo bentonite deposit (Cabo de Gata region, Spain): A natural analogue of the bentonite barrier in a radwaste repository
}

\author{
M. Pelayo ${ }^{\text {a,* }}$, E. García-Romero ${ }^{\text {b }}$, M.A. Labajo ${ }^{\text {a }}$, L. Pérez del Villar ${ }^{\text {a }}$ \\ a Departamento de Medio Ambiente, CIEMAT, Avda. Complutense 22, 28040 Madrid, Spain \\ ${ }^{b}$ Departamento de Cristalografia y Mineralogia, Facultad C.C. Geológicas, UCM, 28040 Madrid, Spain
}

\begin{abstract}
A B S T R A C T
The Morrón de Mateo bentonite deposit is being studied as a natural analogue of the thermal and geochemical effects on a bentonite barrier in a deep geological repository of high level radioactive wastes. This bentonite deposit and its host rocks were intruded by a rhyodacitic volcanic dome that induced a hydrothermal metasomatic process affecting the biocalcarenite beds close to the dome. In this work, the mineralogical and chemical features of the clay minerals of the hydrothermally altered pyroclastic (white tuffs) and epiclastic rocks (mass flow), located in the NE sector of the Morrón de Mateo deposit are described. White tuffs have a high content of phyllosilicates, mainly composed of dioctahedral smectites, while mass flow have a higher proportion of inherited minerals, the neoformed phyllosilicates are dioctahedral smectites and an interlayer chlorite/smectite mineral of corrensite type. The chemical composition of smectites reflects the different nature of the parent rocks, in such a way that smectites from white tuffs have a quite homogeneous chemical composition and their structural formulae correspond to montmorillonite type, while smectites from mass flow show more chemical variability, higher Fe and $\mathbf{M g}$ contents and a mean structural formulae corresponding to $\mathrm{Fe}-\mathrm{Mg}$-rich beidellite and/or to an intermediate smectite member between beidellite and saponite. In addition, chemical composition and textural features of corrensite-like clay minerals in relation to $\mathrm{Fe}-\mathrm{Mg}$-rich smectites in the samples have also been studied, suggesting that the former seems to be formed from Fe-Mg-rich smectites. The presence of corrensite in the epiclastic rocks suggests that in the Morrón de Mateo area a hydrothermal alteration process occurred after bentonite formation, which transformed Fe-Mg-rich smectites into corrensite. This transformation was probably favoured by the intrusion of the Morrón de Mateo volcanic dome, which produced a temperature increase in the geological media and a supply of $\mathrm{Fe}-\mathrm{Mg}$-rich solutions. These physicochemical conditions were also responsible for the metasomatic transformations observed in the biocalcarenite beds located on the top of the bentonite deposit. All these data suggest that the Morron de Mateo natural system could be a good natural analogue of both thermal and chemical effects on a bentonite barrier related to the radioactive decay of fission products and the interaction between the corrosion products of steel over-packs and the bentonite. These circumstances would favour the transformation of the candidate $\mathrm{Al}$-rich smectites into $\mathrm{Fe}-\mathbf{M g}$-rich smectites and corrensite, as steps prior to formation of chlorite. In this case, all the physicochemical and mechanical properties of AI-rich smectites would disappear and the clayey barrier would fail.
\end{abstract}

\section{Introduction}

In the framework of the Spanish programme on a deep geological repository (DGR) for high level radioactive wastes (HLRW), the Morrón de Mateo bentonite deposit (Almeria, Spain) is being studied as a natural analogue of bentonite barrier behaviour after burial, in relation to the thermal and geochemical effects due to radioactive decay of the fission products and the interaction be-

\footnotetext{
* Corresponding author. Fax: +34913466542.

E-mail address: m.pelayo@ciemat.es (M. Pelayo).
}

tween the corrosion products of the steel canister and the bentonite.

The Morrón de Mateo deposit is mainly constituted of $\mathrm{Fe}-\mathrm{Mg}$ rich smectites and Al-smectites (Caballero et al., 1985; Delgado, 1993; Linares et al., 1993; Pérez del Villar et al., 2003, 2005), although corrensite has been sporadically found (Pelayo, 2008; Pelayo et al., 2009). Furthermore, this bentonite deposit, including its host rocks, white tuff and mass flow units, and the biocalcarenite overlaying beds, were intruded by a rhyodacitic volcanic dome that induced a hydrothermal metasomatic process, transforming calcite from the biocalcarenite beds into Fe-Mg-rich calcite, dolomite, 
spherosiderite, ankerite and siderite in the nearest zone to the dome (Pérez del Villar et al., 2003, 2005). The biocalcarenite beds have been assigned to the Lower Tortonian (Betzler et al., 1997), approximately 11.6 Ma ago (Hilgen et al., 2003), while the Morrón de Mateo dome has been dated between 11.3 Ma and 10.8 Ma (Di Battistini et al., 1987; Zeck et al., 2000; Zeck and Whitehouse, 2002). This means that the volcanic intrusion is between $3 \times 10^{5}$ and $8 \times 10^{5}$ a younger than the volcano-sedimentary series. However, though the lava temperature at the moment of intrusion has been estimated at approximately $820^{\circ} \mathrm{C}$, by using the classical FeTi oxides and plagioclase-hornblende geothermometric pairs (Fernández-Soler, 2002), the cooling rate of the volcanic dome and, therefore, the interaction time between the host volcanic body and the smectitised volcano-sedimentary series is difficult to evaluate (Pérez del Villar et al., 2003, 2005). Besides this, the same authors carried out a mineralogical, chemical and isotopic study of the biocalcarenite and bentonite outcropping close to and far from the volcanic dome, specifically in the western quarry of the Morrón de Mateo and the El Murciano quarry, respectively (Fig. 1), observing that smectites close to the dome were dioctahedral Fe-Mg rich-smectites, except in just one sample in which di and trioctahedral smectites coexist. Nevertheless, in distal zones, bentonite is comprised of dioctahedral Al rich-smectites, similar to those from other deposits in the region.

In relation to the temperature gradient in biocalcarenite and smectitised volcano-sedimentary rocks intruded by the dome, the $\delta^{18} \mathrm{O}$ values indicate that smectites close to the dome could be formed or transformed at a temperature range between $55^{\circ} \mathrm{C}$ and $66^{\circ} \mathrm{C}$ (Pérez del Villar et al., 2005). Slightly higher temperatures, between $75^{\circ} \mathrm{C}$ and $95^{\circ} \mathrm{C}$, were obtained by Delgado and Reyes (1993) and Delgado (1993) for smectites located just in contact with the volcanic dome (see Fig. 1) However, the isotopic studies performed on smectites from other bentonite deposits in the region (Delgado, 1993; Delgado and Reyes, 1996) suggested that they were formed at a temperature below $25^{\circ} \mathrm{C}$. In contrast, the isotopic data of distal smectites from the El Murciano quarry also suggest that they were formed under similar temperature as the proximal smectites.

On the other hand, the $\delta^{18} \mathrm{O}$ values of secondary calcite, dolomite and siderite neoformed from biocalcarenite beds located close to the dome indicate that they could be transformed in equilibrium with re-heated seawater at a temperature range between $28^{\circ} \mathrm{C}$ and $90^{\circ} \mathrm{C}$ (Pérez del Villar et al., 2003, 2005). A similar temperature range was obtained from carbonates, mainly calcite, from distal biocalcarenites outcropping in the El Murciano quarry. According to these authors, this fact means that the geological environment where the transformation processes affecting carbonates and smectites reached a relatively similar temperature in the whole studied area. This was likely due to the small size, shallow and semi-closed character of the marine basin, as well as the contemporary and intense geothermal activity in the site, of which the Morrón de Mateo dome was an important, but not unique, volcanic manifestation. As a consequence, the abovementioned authors conclude that a thermal gradient from proximal to close smectites and carbonate samples cannot be established.

All of these data suggest that the intrusion of the dome could be the thermal source for re-crystallization of carbonates and the source of $\mathrm{Fe}, \mathrm{Mg}$ and $\mathrm{Mn}$ that metasomatized the original calcite and transformed $\mathrm{Al}$-smectites into Fe-Mg rich smectites and, eventually, into corrensite, as Pelayo (2008) and Pelayo et al. (2009) evidenced.

Natural Fe-Mg smectites and corrensite have been described in hydrothermally-altered volcanic rocks (Inoue and Utada, 1991). These authors studied corrensite in Miocene volcanoclastic rocks from Kamikita (Japan). In this site, the abovementioned clay minerals were formed by the effect of an intensive thermometamor- phic event, related to the intrusion of a hornblende-rich quartzdiorite. Corrensite has also been described in diagenetic systems (Chang et al., 1986; Hoffman and Hower, 1979); in geothermal fields (Bril et al., 1996; Inoue, 1985, 1987; Liou et al., 1985; Robinson and Santana de Zamora, 1999; Robinson et al., 2002) and in hydrothermal metamorphism developed in the oceanic crust, in both metapelitic (Alt et al., 1986; Buatier et al., 1995) and marly rocks intruded by volcanic rocks (Abad et al., 2003; Einsele, 1986; Kelts, 1982).

Corrensite is formed as an intermediate mineral phase in the Fe$\mathrm{Mg}$-smectite to chlorite transformation process provided that an increase of temperature occurs in the geological environment. The structural and compositional natural changes related to this transformation process have been extensively studied (Inoue and Utada, 1991; Meunier et al., 1991; Robinson et al., 1993, 2002; Shau and Peacor, 1992), as well as the crystalochemical features of this mixed-layer clay mineral (April, 1981; Beaufort and Meunier, 1994; Bergaya et al., 1985; Brigatti and Poppi, 1984; Inoue, 1987). Several authors have reported that the transformation involves a continuous sequence from the interstratified chlorite/smectite phase, increasing the chloritic layers, to chlorite, as the alteration process proceeds (Liou et al., 1985; Robinson et al., 1993; Schiffman and Fridleifsson, 1991). However, other authors consider that the conversion is a discontinuous sequence with steps from smectite to corrensite and from corrensite to chlorite, without any continuous sequence of mixed-layering (Beaufort et al., 1997; Inoue and Utada, 1991; Schmidt and Robinson, 1997; Shau and Peacor, 1992).

Temperature and whole rock composition are considered to be the main factors that control the smectite to chlorite transformation. Nevertheless, Schmidt and Robinson (1997) documented the lithological control in the formation of smectite and chlorite in a low-grade metabasite, located in "the Chipilapa geothermal system" (El Salvador), concluding that the whole rock chemistry is not a main controlling factor for the smectite to chlorite transformation. This suggestion was also confirmed by Robinson and Santana de Zamora (1999).

According to Schiffman and Staudigel (1995) and Schmidt and Robinson (1997) the fluid/rock ratios, the porosity and permeability of the rocks are the most important kinetic controls affecting the fluid and solute transport involved in the smectite-corrensite-chlorite transformation process. Thus, the discontinuous smectite to chlorite transformation represents an equilibrium sequence favoured by a high fluid/rock ratio; while the continuous sequence of mixed-layer phases represent a metastable progression associated with incomplete reaction and/or low fluid/rock ratios (Schiffman, 1995; Schiffman and Staudigel, 1995).

Chemical data from different corrensites show a large compositional variability, which is more evident in octahedral than in tetrahedral coordination (Brigatti and Poppi, 1984). It is observed that Al always constitutes less than $30 \%$ of the octahedral cations, whereas a continuous range between $\mathrm{Fe}$ and $\mathrm{Mg}$ contents exists. The continuous chemical variation of corrensite between trioctahedral chlorite and saponite can be explained on the basis of $\mathrm{Mg}$ and Fe mobilization, probably due to hydrothermal solutions. In particular, Fe appears to play an important role in the chloritesmectite transition (Brigatti and Poppi, 1984).

Beaufort and Meunier (1994) indicated that the chemical composition of corrensite is not well known because of the scarcity of pure corrensite and that only Chl.50/Sap.50 mixed-layering are adequate for the structural formula calculation. These authors conclude that it is possible to propose a structural formula of corrensite in which the tetrahedral sheets of the two 2:1 layer units are identical, as is accepted for phyllosilicates.

In this work the mineralogical and chemical characteristics of bentonites from the NE sector of Morrón de Mateo deposit, in which altered acidic pyroclastic tuffs (white tuffs) and 

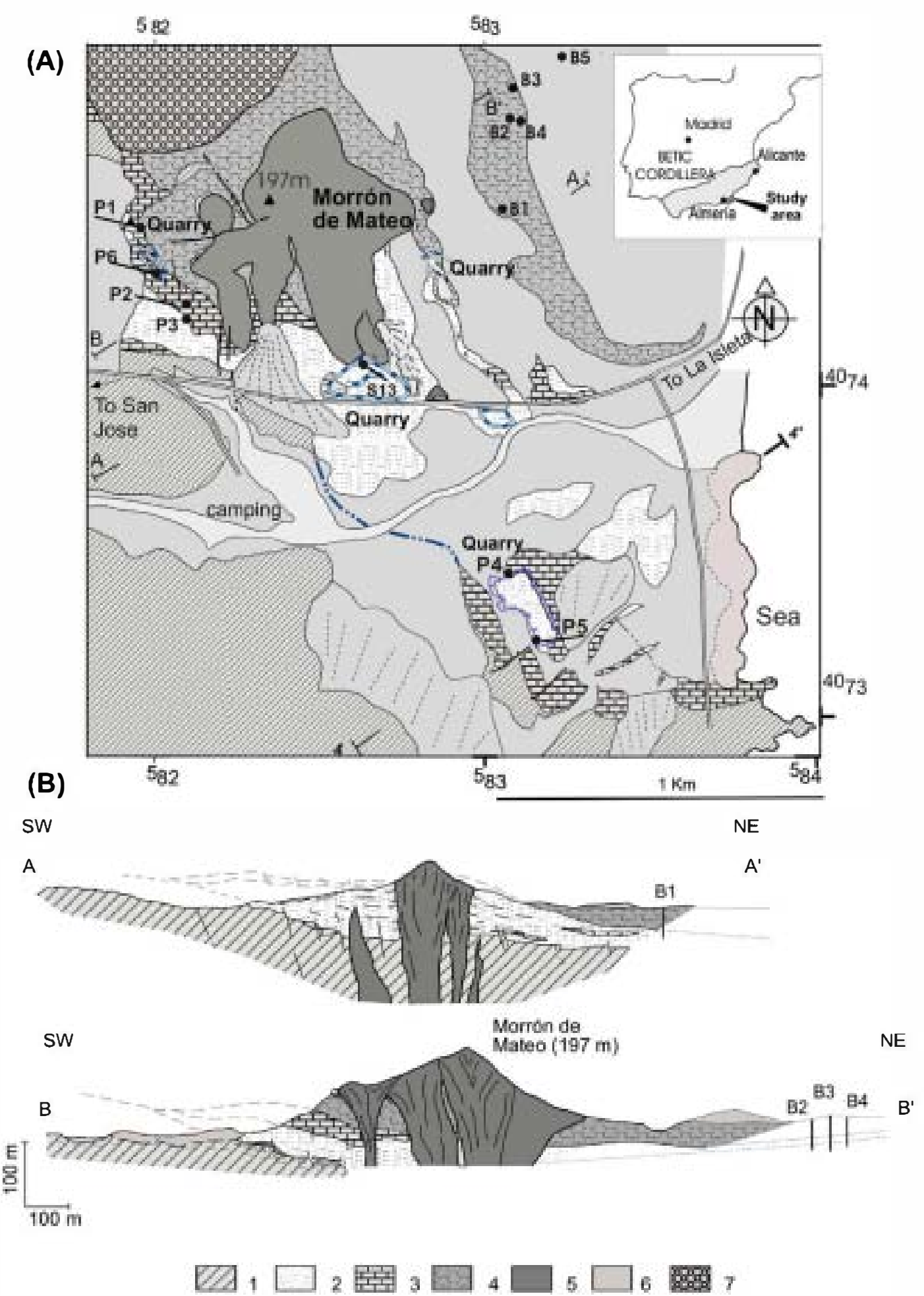

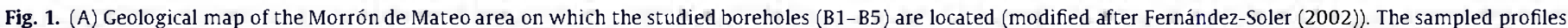

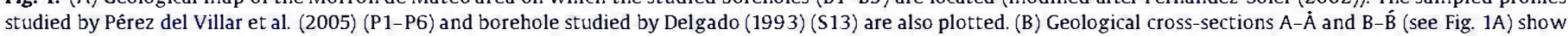

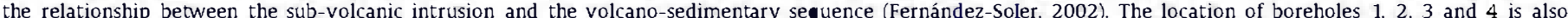

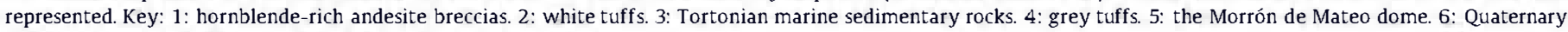
sediments. 7: Rodalquilar complex (rhyo) dacitic rocks.

intermediate epiclastic rocks (mass flow), with a lower alteration degree have been studied. The aims of this contribution are: (i) to characterize the smectites formed from different parent rocks; (ii) to determine if smectite deriving from intermediate epiclastic rocks were affected by post-formational alteration/transformation processes; (iii) to check if the differences observed between the smectites located close to and far from the dome are due to a transformation process or due to the differences in the parent rock nature; and (iv) to predict the possible long-term evolution of the smectite from the engineered barrier, taking into account the results obtained from the Morrón de Mateo bentonite deposit and the DGR Spanish conceptual model. 


\section{Geological setting}

The Morrón de Mateo deposit is located in the central sector of the Cabo de Gata region (Almería), specifically in the Escullos depression, which is placed between the Frailes volcanic structure, to the south, and the Rodalquilar Caldera Complex, to the north (sheet 1060. Pozo de los Frailes, of the National Topographic Map 1:50.000). The Morrón de Mateo dome (197 masl) is a massive lava body that causes a promontory in the Escullos depression. It has been dated between 10.8 and 11.3 Ma old (Di Battistini et al., 1987), and is composed of biotite-hornblende, quartz-rich dacite, with a characteristic red to ochre tint that links this body to the nearby Rodalquilar Caldera Complex (Arribas, 1993; Arribas et al., 1995; Bordet, 1985; Cunningham et al., 1990; FernándezSoler, 1992).

According to Fernández-Soler (2002) the Morrón de Mateo dome intruded a volcano-sedimentary series which mainly consists, from the bottom to the top, of the following geological units: (i) hornblende-rich andesite breccias; (ii) white layered tuffs; (iii) marine sedimentary rocks; and (iv) grey tuffs (Fig. 1). The increase of temperature in relation to this sub-volcanic intrusion induced an intensively altered halo, which is noticeable in the white tuffs; in the marine sedimentary rocks, mainly in the carbonate rocks, and in the grey tuffs

ical characteristics of these materials are:

(i) The hornblende-rich andesite breccias make up the base of the Morrón de Mateo volcano-sedimentary unit and include a variety of hornblende-rich andesitic rocks, which are characterised by the presence of plagioclase and large hornblende phenocrysts. The top of this unit is marked by the presence of a mass-flows deposit, formed by a clast-andesitic rich-breccias immersed in a fine-grained sandy matrix (Fernández-Soler, 2002).

(ii) The white layered tuffs are the main host materials of the Morrón de Mateo bentonite deposit and they are composed of a succession of white-coloured soft layers of bentoniterich tuffs and tabular layers of a brownish to greenish sandy material, poorer in bentonite, that form the base surge and co-surge hydromagmatic facies. The sequence of layered tuffs is sub-horizontal or low angle dipping to the east, but the intrusion dragged and folded the layered sequence in its proximity. This unit may reach a thickness of $60-70 \mathrm{~m}$, decreasing towards the east. This formation shows some sedimentary structures that point to lateral currents as main transport and deposition mechanisms. These features suggest that the white layered tuffs may have formed as a result of phreatomagmatic activity occurring by magma-water interaction in a shallow marine environment, probably in a depressed coastal embayment (Fernández-Soler, 1987, 1992; Fernández-Soler and Muñoz, 1988). Smectites studied by Pérez del Villar et al. $(2003,2005)$ come from the alteration of these phreatomagmatic materials.

(iii) Marine sedimentary rocks are placed unconformably on top of the white tuffs. This formation is not continuous in all the deposit area, since it occurs in the upper western part, while towards the east it only forms isolated outcrops without lateral continuity. The main lithological unit is a bioclastic calcarenite about $20 \mathrm{~m}$ thick composed of heterometric clasts of bryozoa, echinoderms and bivalves. This biological association is typical of temperate climate carbonates, which are widespread through the Lower Tortonian basin in the Cabo de Gata region. The calcarenite gradually and irregularly passes to reddish Fe-metasomatized limestones in the proximity to the Morrón de Mateo dome. According to stable isotope studies on the carbonate minerals (Delgado, 1993), the ferrous carbonates were formed as a result of the migration of hot marine fluids, probably activated by the Morrón de Mateo dacite dome.

(iv) The grey tuffs make up a single, massive, unstructured or faintly layered unit, unconformably overlaying the marine sedimentary rocks or directly on the top of the white tuffs towards the east of Morrón de Mateo area. These facies were formed by reworking of a py roxene andesite parent rock in a shallow marine environment by similar mechanisms to mass-flows (Fernández-Soler, 2002). They are grey-greenish coloured rocks, mainly composed of heterometric, pumicepoor, lithic brecciaswith glassy matrix. The glassy component is altered to smectite, but the extracted bentonite seems to be much less pure than that obtained from the underlying white tuffs (Fernández-Soler, 2002). In this study, it has been found that this unit is a mass flow formation. For this reason, from now on, this unit will be referred as "mass flow" for clarity.

\section{Materials and methods}

A total of 34 samples were collected from five boreholes located in the NE zone of the Morrón de Mateo area (Fig. 1), also in this figure the sampled profiles studied by Pérez del Villar et al. (2003, 2005) and samples from the borehole studied by Delgado (1993) are plotted for comparison.

The depth of the studied boreholes varies from 15 to $25 \mathrm{~m}$. Samples come from mass flow, white tuffs and amphibolic-andesite breccias units, as well as, from a transition zone between mass flow and white tuffs units. The studied boreholes and the correlation between them are shown in Fig. 2 .

The mass flow unit has a greenish-grey colour, with sand-size grains and is mainly composed of rock fragments, quartz, feldspars and amphibole crystals immersed in a partially bentonitized finegrained matrix. However, in borehole 1 , this lithological unit is more fine-grained $(\approx 2 \mathrm{~mm})$ and homometric, its matrix being more greenish in colour. The white tuffs unit is of white-ochre colour with an earthy aspect. It is highly bentonitized and includes some inherited minerals, such as hornblende and feldspar fragments. This unit, with a thickness that varies from 3 to $6 \mathrm{~m}$, has only been intersected by boreholes 2, 3 and 4 (see Fig. 2). The amphibole-andesite breccias unit is of grey-beige colour and has been intersected by boreholes 3,4 and 5 .

Bulk samples were dried in a forced air oven at $40^{\circ} \mathrm{C}$ for $48 \mathrm{~h}$ and then ground and homogenised in an agate ball grinder. Afterwards, they were sieved to a $<60 \mu \mathrm{m}$ grain size, using a ny lon mesh ASTM sieve.

The semi-quantitative mineralogical composition of the bulk samples was determined by the powder X-ray diffraction (XRD) method, using the reflections proposed by Schultz (1964) and Barahona (1974), and the calculation method proposed by Bradley and Grim (1961). A "X" Pert-MPD Philips diffractometer, Cu K $\alpha$ radiation and a scan speed of $2^{\circ}, 2 \theta / \mathrm{min}$ were used.

A scanning electron microscope (Zeiss DSM 960) coupled to an energy dispersive X-ray analytical Link eXL system (SEM + EDX), was used to study representative fresh-surfaces from fragments and thin polished sections of the smectitised materials, previously coated with Au to facilitate the electron conductivity of the specimens. Some backscattered electron images were taken to illustrate the most relevant textural features of the samples. Besides this, a Jeol JSM 6330F Field Emission Gun (FEG) has also been used, in order to obtain electron images with higher resolution.

Clayey fractions $(<2 \mu \mathrm{m})$ were extracted by the conventional sedimentation method. Air dried oriented specimens, treated with ethylene glycol (EG) and heated at $550^{\circ} \mathrm{C}$ for $2 \mathrm{~h}$ were analyzed by 
$\mathrm{XRD}$ in the $2-35^{\circ} 2 \theta$ range for mineral identification. XRD patterns of the EG-solvated oriented specimens, the reflections proposed by Barahona (1974) for clay minerals and the Bradley and Grim (1961) calculation method were used for semi-quantitative estimations. The interstratified clay minerals were determined by comparing the observed XRD patterns with computer-simulated patterns, using the Newmod program (Reynolds, 1985).

Chemical analyses of the smectites were carried out with a JEOL-200Kv JEM 2000 FX transmission electron microscope coupled to an energy dispersive X-ray analytical system (TEM + EDX). These analyses were carried out in the "Luis Brú" Electron Microscopy Centre of the University Complutense of Madrid. The structural formulae of smectites were calculated on the basis of 22 oxygens per unit cell. All Fe is considered to be $\mathrm{Fe}^{3+}$, due to the limitation of the technique. Chemical analyses of corrensite were carried out on polished thin-sections by using the above mentioned $\mathrm{SEM}+\mathrm{EDX}$ in the Environmental Department of CIEMAT. This technique has been used due to the difficulty of finding isolated corrensite particles by using TEM + EDX. The structural formulae of corrensite were calculated from these data on the basis of 50 oxygens per unit cell, assuming that all $\mathrm{Fe}$ is $\mathrm{Fe}^{2+}$.

\section{Results and discussion}

\subsection{Mineralogy and textural features}

The semi-quantitative mineralogical composition of the white tuffs, mass flow and andesite breccia bulk samples is listed in Table 1. All the samples are composed of $14 \AA$ phyllosilicates, minor feldspars, quartz and calcite and scarce amphiboles, zeolites and cristobalites. Phyllosilicates are the main phases, varying in content between $35 \%$ and $85 \%$. Calcite appears in almost all the samples in different proportions. Feldspar content is generally higher than that of quartz, except in samples from borehole 1. Zeolites and amphiboles occur sporadically and generally as trace minerals. White tuffs have the highest phyllosilicate contents (60-85\%), while mass flow and andesitic breccia units contain greater amounts of inherited minerals, such as quartz, feldspars and amphiboles.

Samples from the mass flow formation, except those from borehole 1 , have two (060) reflections at $1.52 \AA$ and $1.50 \AA$, which correspond to 060 lattice planes of tri and dioctahedral smectites, respectively, while samples from white tuffs only show the 060 reflection at $1.50 \AA$, indicating the presence of only dioctahedral smectites (Fig. 3). Furthermore, samples from borehole 1 have two (060) reflection at about $1.54 \AA$ and $1.50 \AA$, the first probably corresponding to a chlorite-type phyllosilicate and the second to a dioctahedral smectite.

The mineralogical composition of the $<2 \mu \mathrm{m}$ fraction (see Table 1) shows that smectite is the major mineral in all the samples, except in samples from the mass flow formation intersected by borehole 1, which are composed of a mixture, in different proportions, of an ordered (R1) chlorite/smectite interstratified clay mineral (corrensite) and smectite, the corrensite always being the main phase. Fig. 4A displays representative XRD patterns of samples from borehole 1 (closest to the volcanic dome). The air-dried pattern shows a superstructure (001) at 29.6, (002) 14.7 and (003) $7.3 \AA$ \&hich correspond to corrensite. The ethylene glycol solvated specimens give coherent patterns, showing a superstructure (001) at $31.1,15.6$ and $7.8 \AA$. The heat-treated specimens also show

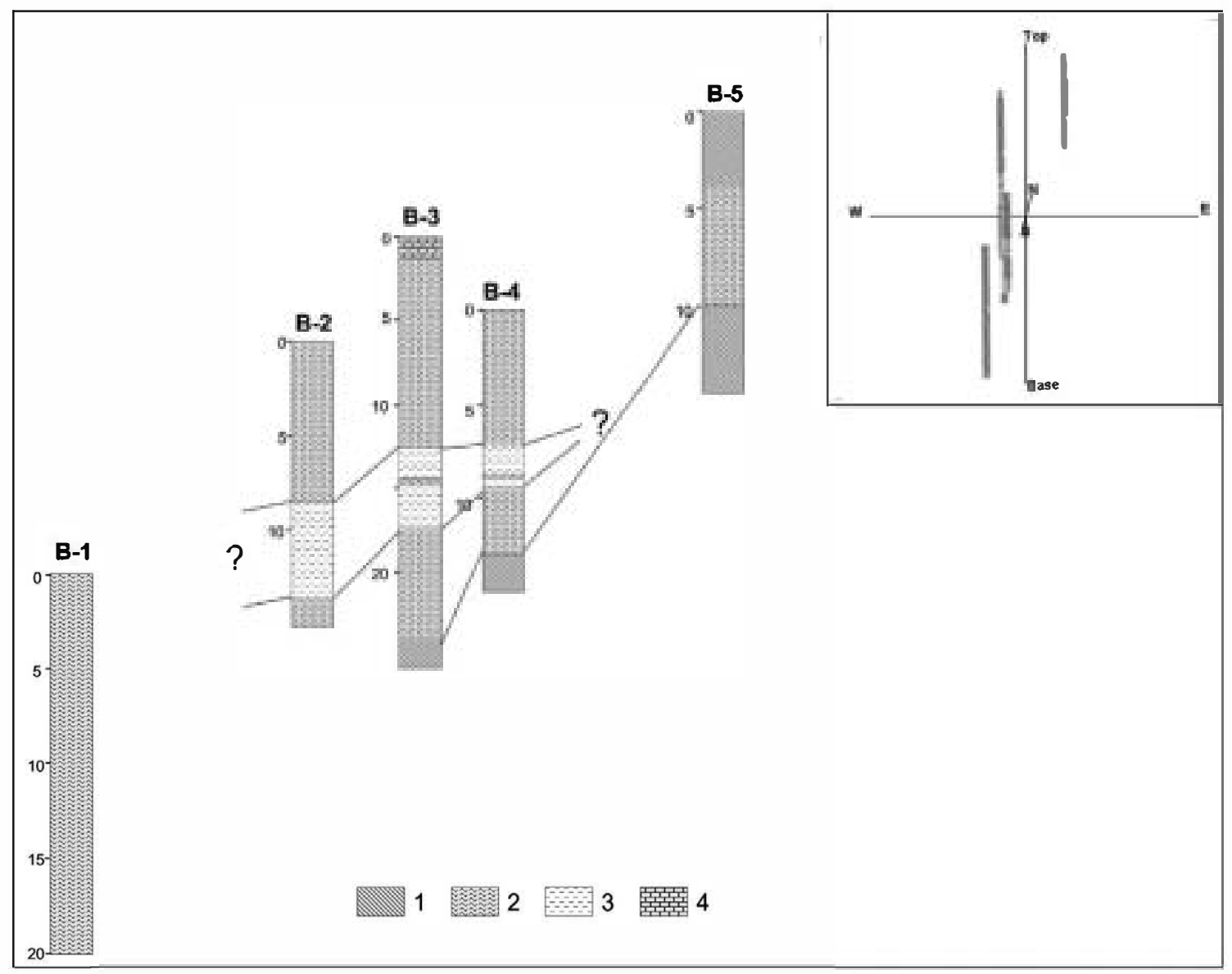

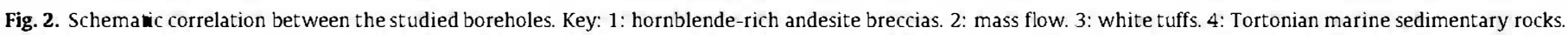


Table 1

Semi-quantitative mineralogical composition of the bulk and clayey samples.

\begin{tabular}{|c|c|c|c|c|c|c|c|c|c|c|c|c|c|c|}
\hline \multirow[t]{2}{*}{ Borehole } & \multirow[t]{2}{*}{ Samples } & \multirow[t]{2}{*}{ Depth (m) } & \multirow[t]{2}{*}{ Lithology } & \multicolumn{7}{|c|}{ Bulk sample (wt: } & \multicolumn{4}{|c|}{$<2 \mu \mathrm{m}$ fraction (wt\%) } \\
\hline & & & & $Q z$ & $\mathrm{Fd}$ & Amp & Zeol & Cris & $\mathrm{Cc}$ & T.Ph. & $\mathrm{Sm}$ & Cor & $\mathrm{Chl} / \mathrm{Sm}$ & Illi \\
\hline \multirow[t]{7}{*}{ B-1 } & M1 & 1.6 & Mass flow & 20 & 20 & $\mathrm{Tr}$ & - & $\mathrm{Tr}$ & 10 & 50 & 30 & 70 & - & - \\
\hline & $\mathrm{M} 2$ & 2.6 & Mass flow & 20 & 15 & 5 & - & $\mathrm{Tr}$ & 15 & 45 & 30 & 70 & - & - \\
\hline & M3 & 5.8 & Mass flow & 25 & 5 & $\mathrm{Tr}$ & - & $\mathrm{Tr}$ & 20 & 50 & 20 & 80 & - & - \\
\hline & M4 & 6.8 & Mass flow & 15 & 10 & $\mathrm{Tr}$ & $\mathrm{Tr}$ & $\mathrm{Tr}$ & $\operatorname{Tr}$ & 75 & 35 & 55 & - & 10 \\
\hline & M5 & 9.8 & Mass flow & 10 & 5 & $\mathrm{Tr}$ & $\mathrm{Tr}$ & $\operatorname{Tr}$ & 15 & 70 & 20 & 70 & - & 10 \\
\hline & M6 & 14.4 & Mass flow & 15 & 5 & - & $\operatorname{Tr}$ & $\mathrm{Tr}$ & 10 & 70 & 15 & 75 & - & 10 \\
\hline & M7 & 16.8 & Mass flow & 15 & 5 & - & $\mathrm{Tr}$ & - & 10 & 70 & 25 & 65 & - & 10 \\
\hline \multirow[t]{6}{*}{ B-2 } & M1 & 0.9 & Mass flow & 10 & 15 & $\operatorname{Tr}$ & - & 5 & 10 & 60 & 100 & - & Ir & - \\
\hline & M2 & 3.3 & Mass flow & 15 & 25 & $\operatorname{Tr}$ & - & 10 & $\operatorname{Tr}$ & 50 & 100 & $=$ & $=$ & $=$ \\
\hline & M3 & 7.5 & Mass flow & 15 & 15 & $\operatorname{Tr}$ & - & 10 & 15 & 45 & 100 & - & - & - \\
\hline & M4 & 8.7 & White tuffs & 5 & 5 & - & $\mathrm{Tr}$ & $=$ & 20 & 70 & 100 & $=$ & - & - \\
\hline & M5 & 11.8 & White tuffs & 5 & 10 & $\operatorname{Tr}$ & $\mathrm{Tr}$ & 5 & 10 & 70 & 100 & - & - & - \\
\hline & M6 & 13.5 & White tuffs & $\operatorname{Tr}$ & 5 & $\operatorname{Tr}$ & $\mathrm{Tr}$ & 5 & 10 & 80 & 100 & - & - & - \\
\hline \multirow[t]{9}{*}{ B-3 } & M1 & 2.0 & Mass flow & 5 & 10 & $\mathrm{Tr}$ & - & 5 & 10 & 70 & 95 & - & - & 5 \\
\hline & $\mathrm{M} 2$ & 6.5 & Mass flow & 10 & 25 & $\operatorname{Tr}$ & - & 5 & 10 & 50 & 100 & - & - & - \\
\hline & M3 & 11.1 & Mass flow & 10 & 20 & $\operatorname{Tr}$ & - & 10 & 20 & 40 & 95 & - & - & 5 \\
\hline & M4 & 12.8 & White tuffs & 5 & 20 & $\operatorname{Tr}$ & 5 & $\operatorname{Tr}$ & 10 & 60 & 90 & - & - & $\operatorname{Tr}$ \\
\hline & M5 & 13.8 & White tuffs & 5 & 10 & - & $\mathrm{Tr}$ & $\operatorname{Tr}$ & 10 & 75 & 100 & - & - & $\operatorname{Tr}$ \\
\hline & M6 & 14.6 & White tuffs & 5 & 5 & $\operatorname{Tr}$ & 5 & $\operatorname{Tr}$ & 10 & 75 & 100 & - & - & $\operatorname{Tr}$ \\
\hline & M7 & 17.4 & Transition & 15 & 15 & $\mathrm{Tr}$ & $\mathrm{Tr}$ & 5 & 10 & 55 & 100 & - & - & $\operatorname{Tr}$ \\
\hline & M8 & 20.3 & Mass flow & $\mathrm{Tr}$ & 5 & $\operatorname{Tr}$ & $\mathrm{Tr}$ & 5 & 35 & 55 & 100 & - & - & - \\
\hline & M9 & 24.9 & Breccias & 20 & 25 & $\operatorname{Tr}$ & - & 10 & 5 & 40 & 95 & - & 5 & $\operatorname{Tr}$ \\
\hline \multirow[t]{8}{*}{$B-4$} & M1 & 1.5 & Mass flow & 15 & 20 & $\mathrm{Tr}$ & - & 10 & - & 55 & 100 & - & - & $\mathrm{Tr}$ \\
\hline & $\mathrm{M} 2$ & 3.3 & Mass flow & 10 & 15 & $\mathrm{Tr}$ & - & 5 & 10 & 60 & 100 & - & Ir & - \\
\hline & M3 & 5.7 & Mass flow & 10 & 15 & $\mathrm{Tr}$ & Tr & 10 & - & 70 & 100 & $=$ & - & $\mathrm{Tr}$ \\
\hline & M4 & 7.7 & White tuffs & 5 & 5 & - & - & $\operatorname{Tr}$ & 5 & 85 & 100 & - & - & - \\
\hline & M5 & 8.6 & White tuffs & 5 & 5 & - & - & 5 & - & 85 & 100 & - & - & - \\
\hline & M6 & 9.7 & Transition & 15 & 15 & - & - & 5 & 5 & 60 & 100 & - & - & - \\
\hline & M7 & 11.6 & Mass flow & 10 & 15 & $\mathrm{Tr}$ & $=$ & 2 & 15 & 60 & 100 & - & - & - \\
\hline & M8 & 13.7 & Breccias & 25 & 15 & $\operatorname{Tr}$ & Tr & $\operatorname{Tr}$ & 15 & 45 & 95 & - & 5 & - \\
\hline \multirow[t]{4}{*}{ B-5 } & M1 & 5.1 & Mass flow & 30 & 20 & $\mathrm{Tr}$ & - & 5 & 10 & 35 & 100 & - & $\mathrm{Tr}$ & - \\
\hline & $\mathrm{M} 2$ & 8.7 & Mass flow & 15 & 10 & $\mathrm{Tr}$ & $\mathrm{Tr}$ & 5 & 5 & 65 & 100 & - & $\operatorname{Tr}$ & - \\
\hline & M3 & 9.9 & Mass flow & 15 & 15 & $\operatorname{Tr}$ & $\mathrm{Tr}$ & $\mathrm{Tr}$ & 5 & 65 & 100 & - & $\mathrm{Tr}$ & - \\
\hline & M4 & 13.9 & Breccias & 15 & 10 & $\mathrm{Tr}$ & - & 5 & 20 & 50 & 100 & - & $\mathrm{Tr}$ & - \\
\hline
\end{tabular}

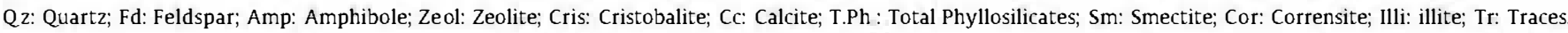
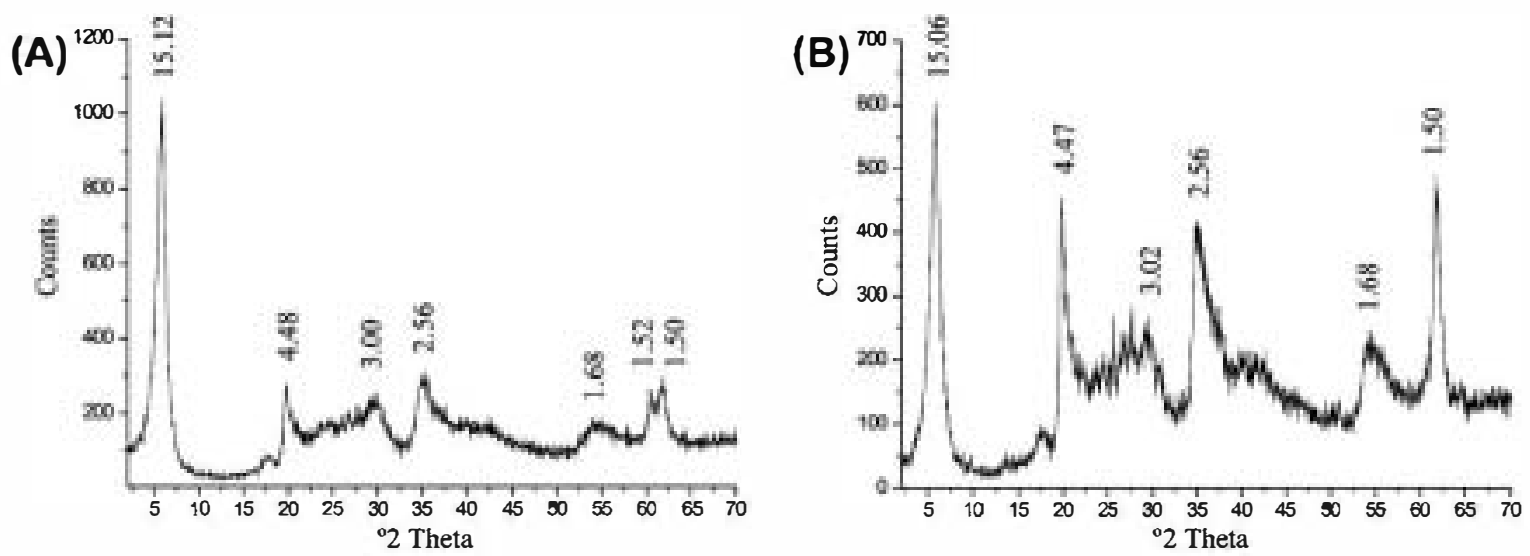

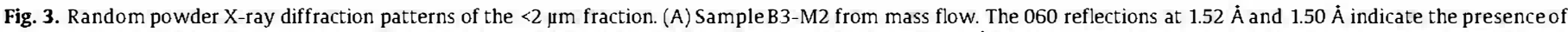

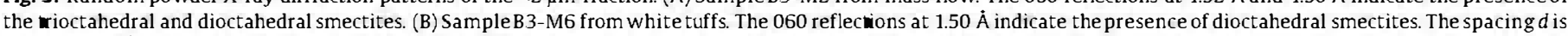
expressed in $\dot{A}$.

coherent XRD patterns, with peaks at 23 and $12.7 \AA$ As mentioned above, these samples also contain smectites that was identified by means of the reflection at $8.2 \AA$ on the ethylene glycol solvated patterns and at $9.9 \AA$ A on the heat-treated patterns. The (002) reflection of corrensite is overlapped by the main reflections at $14 \AA$ (Air dried form) and $16 \AA$ (Ethylene glycol solvated form) of smectites. The $<2 \mu \mathrm{m}$ XRD patterns of samples from the mass flow formation intersected by the other boreholes only show traces of a random chlorite/smectite interstratified clay mineral (Fig. 4 B) which exhibits a spacing at $7.3 \AA$ in the air dried samples and a reflection at $7.6 \AA$ after the ethylene glycol solvation treatment. This interstratified clay mineral could be an intermediate phase in the smectite to corrensite transformation process (Robinson et al., 1993). However, the low proportion of this interstratified mineral prevents being more precise using only XRD data. Nevertheless, samples from white tuffs are essentially formed of only smectites as shown 

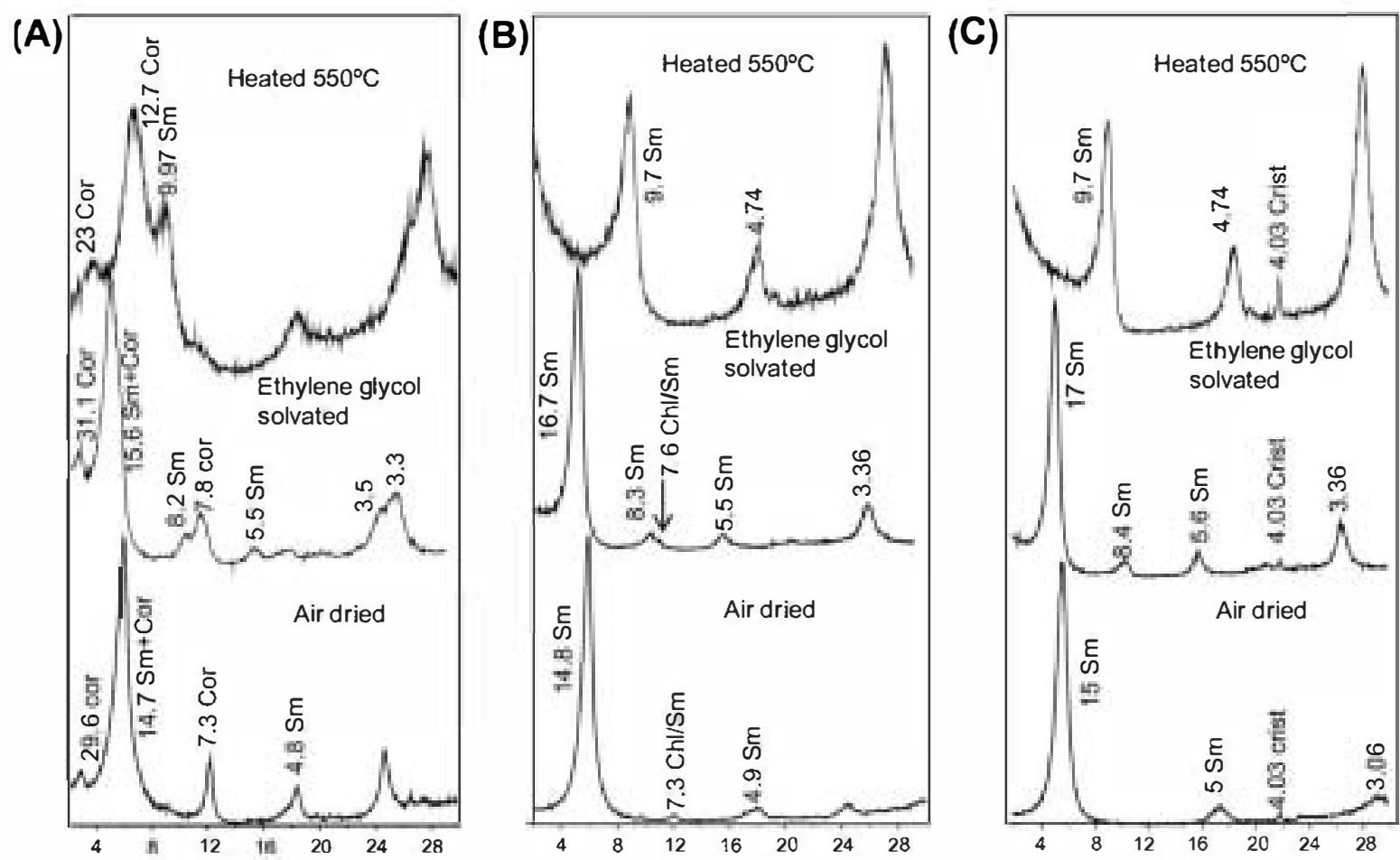

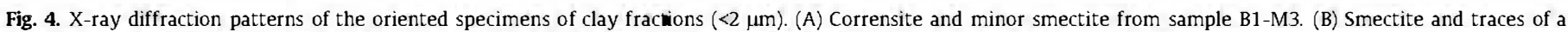
chlorite/smectite interstratified mineral from sample B4-M2. (C) Smectite from sample B2-M6. The spacing $d$ is expressed in $\dot{A}$.

in Fig. $4 \mathrm{C}$. The air dried pattern exhibits basal spacing of $15 \AA$ which expands to $17 \AA ̊$ in ethylene glycol solvated samples and collapses to 9.7 upon heating to $550^{\circ} \mathrm{C}$.

SEM and FEG observations of samples show that smectite is formed by an alteration process, replacing both plagioclases (Fig. 5A) and volcanic glass (Fig. 5B). The smectite flakes coat the surface of plagioclases and glassy volcanic fragments and, occasionally, they form spherical aggregates with honeycomb morphology (Fig. 5C). In detail, smectite shows elongated and webby flakes, with curled edges (Fig. 5D). These morphologies are similar in both, mass flow and white tuffs units.

A sheet mineral with plates varying between 10 and $20 \mu \mathrm{m}$ in size appears in all the samples from the mass flow unit (Fig. 6A). This mineral shows face to face orientated sheets and contains higher $\mathrm{Fe}$ and $\mathrm{Mg}$ than smectites, according EDX analyses, and probably corresponds to corrensite, previously described on XRD data. The relationships between this interstratified mineral and smectite indicate that the former probably comes from the transformation of smectite, as shown in Fig. $6 \mathbf{B}$.

\subsection{Clay mineral chemistry}

\subsubsection{Smectites}

Nine samples of smectites from white tuffs and mass flow units were selected for chemical analysis by TEM + EDX. Chemical composition and structural formulae of smectites from white tuffs and the transition zone between both units are listed in Table 2. For comparison, analyses of two representative smectites studied by Pérez del Villar et al. $(2003,2005)$ are also given. Analyses of smectites from mass flow unit are listed in Table 3.

Smectites from the white tuffs unit (Table 2) have a more homogeneous chemical composition than smectites from the mass flow unit (Table 3). The former have higher $\mathrm{SiO}_{2}$ and lower $\mathrm{Fe}_{2} \mathrm{O}_{3}$ and $\mathrm{MgO}$ contents than smectites from the mass flow, with $\mathrm{MgO}$ contents being higher than $\mathrm{Fe}_{2} \mathrm{O}_{3}$. In contrast, in smectites from mass flow unit the $\mathrm{Fe}_{2} \mathrm{O}_{3}$ content is higher than MgO. Smectites from the mass flow unit show higher compositional variability; which is demonstrated by higher values of standard deviation (see Tables 2 and 3 ).

The structural formulae of smectites from the white tuffs unit show a prevalence of octahedral charge, varying from 0.25 and 0.60 per unit cell whereas the tetrahedral one varies from 0.09 to 0.14 p.u.c. The $\mathrm{Fe}^{3+}$ ranges between 0.42 and 0.52 atoms and the $\mathrm{Mg}$ between 1.21 and 1.22 atoms p.u.c. The number of octahedral cations varies from 4.21 to 4.30 p.u.c. Consequently, smectites from the white tuffs are montmorillonites with the following average structural formula:

$\left(\mathrm{Si}_{7.90} \mathrm{Al}_{0.10}\right)\left(\mathrm{Al}_{2.58} \mathrm{Fe}_{0.45} \mathrm{Mg}_{1.24}\right)(\mathrm{Ca}, \mathrm{Na}, \mathrm{K})_{0.53} \mathrm{O}_{20}(\mathrm{OH})_{4}$

On the other hand, the structural formulae of smectites from the mass flow unit have a predominance of tetrahedral charge, ranking from 0.3 to 1.13 per unit cell, while octahedral charge varies from 0.13 to 0.70 p.u.c. They have between 0.70 and 0.90 atoms of $\mathrm{Fe}^{3+}$ and between 1.49 and 1.74 atoms of $\mathrm{Mg}$ p.u.c. The number of octahedral cations varies from 4.41 to 4.75 p.u.c., which is higher than those from the white tuffs. As a consequence, the smectites from this unit are beidellites. Their average structural formula is as follows:

$\left(\mathrm{Si}_{7.57} \mathrm{Al}_{0.43}\right)\left(\mathrm{Al}_{2.02} \mathrm{Fe}_{0.87} \mathrm{Mg}_{1.59}\right)(\mathrm{Ca}, \mathrm{Na}, \mathrm{K})_{062} \mathrm{O}_{20}(\mathrm{OH})_{4}$

However, there are some smectite particles from the mass flow of borehole 1 which show intermediate composition between beidellite and saponite on the basis of their charge distribution and their total content of octahedral cations. A common characteristic of all these smectites is that the main octahedral cation is $\mathrm{Al}$, followed by $\mathrm{Mg}$ and $\mathrm{Fe}^{3+}$.

If the chemical composition of smectites from this study (white tuffs) is compared with those from Pérez del Villar et al. (2003, 2005) (see Table 2) it is observed that the former have a more homogeneous chemical composition, slightly higher $\mathrm{SiO}_{2}$ and $\mathrm{Al}_{2} \mathrm{O}_{3}$ and lower $\mathrm{Fe}_{2} \mathrm{O}_{3}$ and $\mathrm{MgO}$ contents than smectites close to the volcanic dome (proximal smectites), despite both smectites 

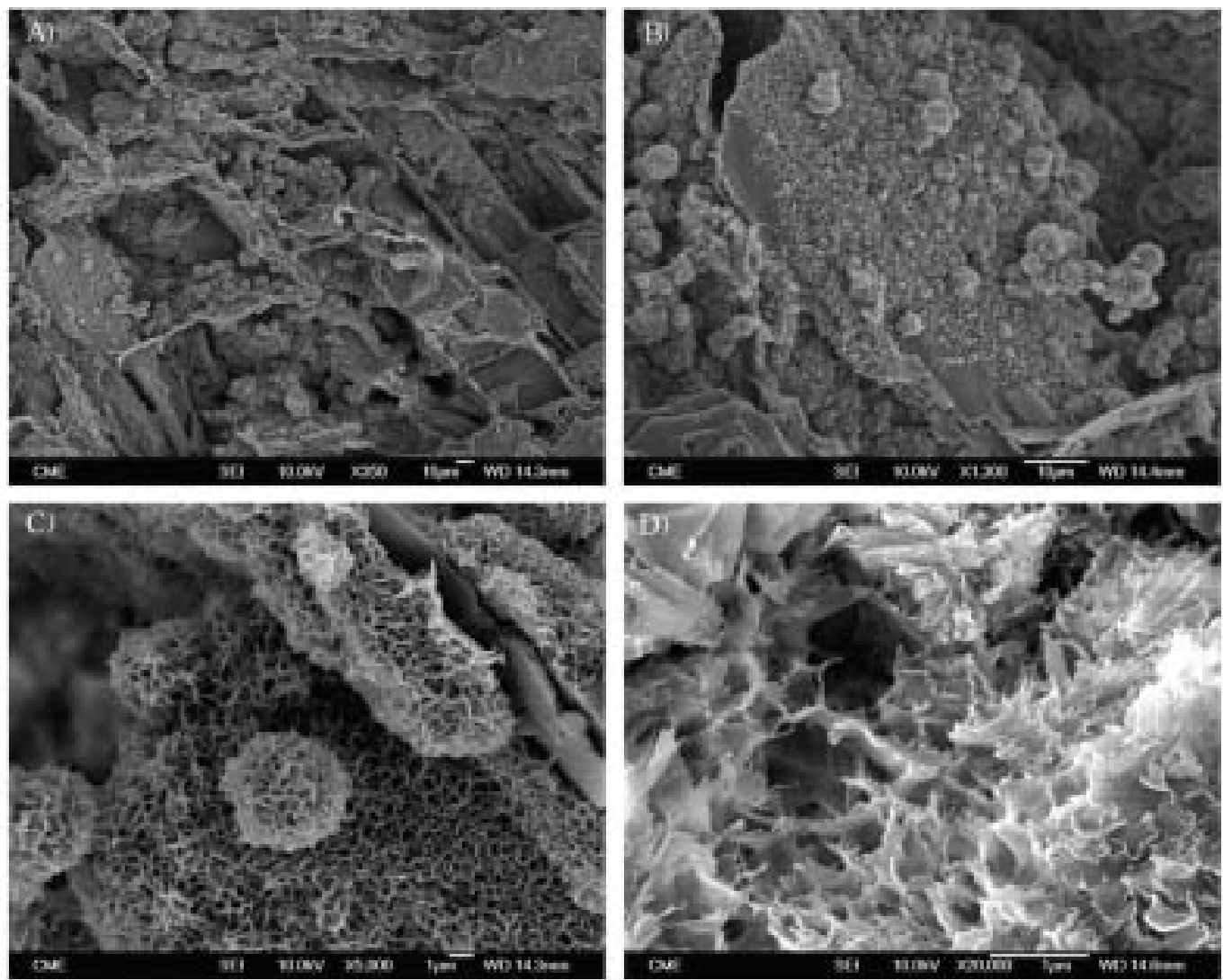



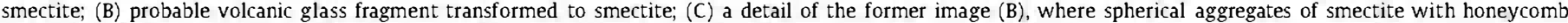
morphology is observed; (D) smectite showing a webby morphology and curled edges.
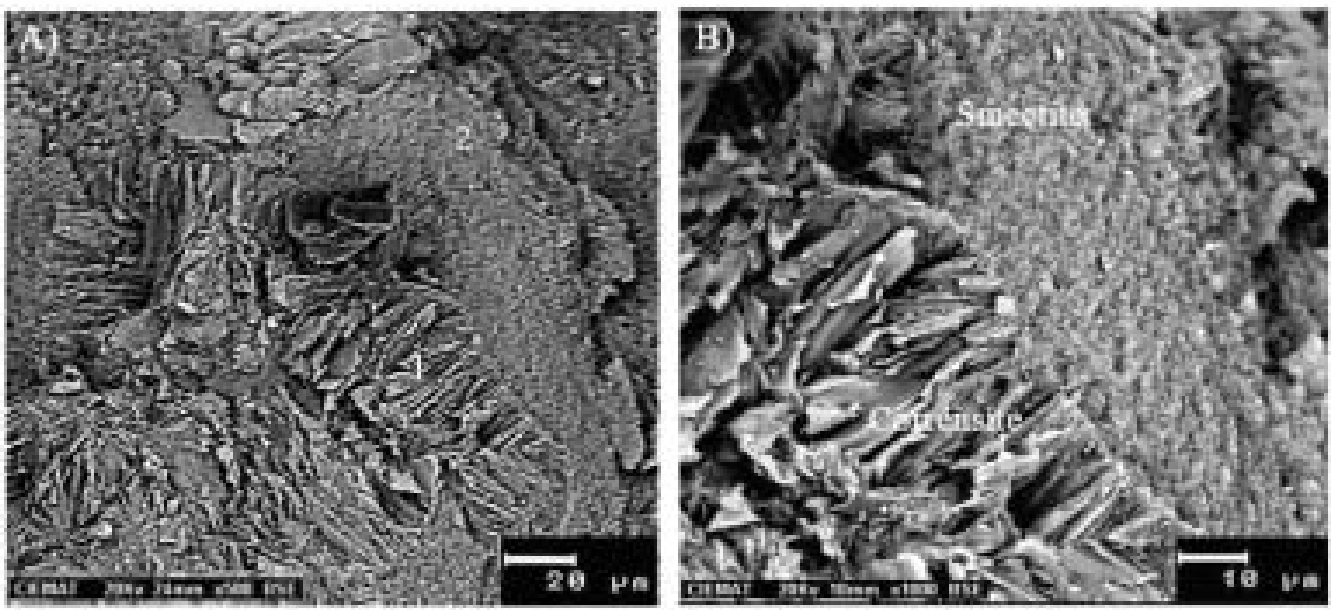

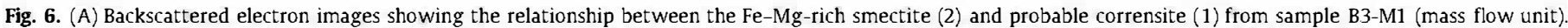
Point 3 shows a probable neoformed K-feldspar; (B) magnification of the previous image where the ransformation of smectite to probable corrensite is observed.

coming from the same parent rock (white tuffs). In contrast, the smectites from this study have a similar chemical composition to those located far from the dome (distal smectites). However, chemical composition of smectites from the mass flow unit (see Table 3) is similar to those located close to the volcanic dome or proximal smectites.

The relationship between $\mathrm{Fe}^{3+}$ and $\mathrm{Al}^{\mathrm{VI}}$ of all smectites shows an obvious negative trend, with a correlation coefficient value $(r)$ of -0.806 and -0.877 for smectites from the white tuffs (acidic parent rocks) and the mass flow (intermediate parent rocks) units, respectively (Fig. 7A). Christidis and Dunham (1997) reported a similar relationship in bentonites derived from the alteration of intermediate volcanic rocks from Milos Island (Greece). However, they obtained a weak relationship in bentonites from the alteration of acidic precursors.

A weak negative relationship is observed between $\mathrm{Mg}$ and $\mathrm{Al}^{\mathrm{VI}}$, with $r$ value of -0.498 in smectites from white tuffs and a better negative relationship $(r=-0.698)$ in smectites from the mass flow unit (Fig. 7B). The more obvious relationship between $\mathrm{Fe}^{3+}$ and $\mathrm{Al}^{\mathrm{VI}}$ than $\mathrm{Mg}$ and $\mathrm{Al}^{\mathrm{VI}}$, especially in smectites from the mass flow unit, 
Table 2

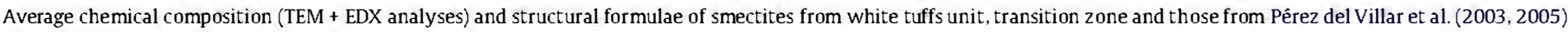
for comparison (MTO-7 and MTO-14).

\begin{tabular}{|c|c|c|c|c|c|c|c|c|c|c|c|c|}
\hline \multirow[t]{2}{*}{ wt\% } & \multicolumn{2}{|c|}{$\begin{array}{l}\text { B2-M6 } \\
(n=10) \\
\end{array}$} & \multicolumn{2}{|c|}{$\begin{array}{l}\text { B3-M6 } \\
(n=11) \\
\end{array}$} & \multicolumn{2}{|c|}{$\begin{array}{l}\text { B4-M4 } \\
(n=10) \\
\end{array}$} & \multicolumn{2}{|c|}{$\begin{array}{l}\text { B3-M7 }(n=11) \text { Transition } \\
\text { zone }\end{array}$} & \multicolumn{2}{|c|}{$\begin{array}{l}\text { MTO-7 }(n=10) \text { Proximal } \\
\text { smectites }\end{array}$} & \multicolumn{2}{|c|}{$\begin{array}{l}\text { MTO-14 }(n=10) \text { Distal } \\
\text { smectites }\end{array}$} \\
\hline & Mean & sd & Mean & sd & Mean & sd & Mean & sd & Mean & sd & Mean & sd \\
\hline $\mathrm{SiO}_{2}$ & 66.56 & 0.66 & 66.19 & 1.30 & 66.00 & 0.68 & 64.47 & 3.09 & 64.54 & 2.14 & 66.94 & 0.66 \\
\hline $\mathrm{Al}_{2} \mathrm{O}_{3}$ & 19.42 & 0.49 & 18.57 & 1.03 & 19.27 & 0.68 & 17.17 & 2.16 & 16.12 & 1.41 & 18.96 & 0.74 \\
\hline $\mathrm{Fe}_{2} \mathrm{O}_{3}$ & 4.68 & 0.63 & 5.26 & 1.34 & 5.61 & 0.75 & 8.21 & 3.97 & 7.89 & 0.56 & 4.58 & 0.22 \\
\hline $\mathrm{MgO}$ & 6.85 & 0.35 & 6.81 & 1.01 & 6.93 & 0.50 & 8.00 & 0.93 & 8.58 & 0.71 & 7.32 & 0.39 \\
\hline $\mathrm{K}_{2} \mathrm{O}$ & 0.44 & 0.06 & 1.43 & 0.64 & 0.32 & 0.13 & 0.76 & 0.36 & 0.30 & 0.68 & 0.38 & 0.34 \\
\hline $\mathrm{CaO}$ & 1.27 & 0.13 & 1.22 & 0.36 & 0.99 & 0.22 & 1.34 & 0.50 & 1.82 & 0.69 & 0.67 & 0.59 \\
\hline $\mathrm{Na}_{2} \mathrm{O}$ & 0.64 & 0.17 & 0.53 & 0.63 & 0.77 & 0.23 & 0.05 & 0.17 & 0.61 & 0.77 & 1.16 & 0.86 \\
\hline \multicolumn{13}{|c|}{$\begin{array}{l}\text { Numbers of cations on the basis of } \mathrm{O}_{2}(\mathrm{OH})_{4} \\
\text { Tetrahedral cations }\end{array}$} \\
\hline $\mathrm{Si}$ & 7.91 & 0.06 & 7.91 & 0.12 & 7.86 & 0.05 & 7.77 & 0.23 & 7.76 & 0.21 & 7.92 & 0.05 \\
\hline $\mathrm{Al}^{\mathrm{IV}}$ & 0.09 & 0.06 & 0.09 & 0.12 & 0.14 & 0.05 & 0.23 & 0.23 & 0.24 & 0.21 & 0.08 & 0.05 \\
\hline \multicolumn{13}{|l|}{ Octahedral cations } \\
\hline $\mathrm{Al}^{\mathrm{VI}}$ & 2.63 & 0.06 & 2.53 & 0.18 & 2.56 & 0.10 & 2.21 & 0.43 & 2.05 & 0.08 & 2.56 & 0.09 \\
\hline $\mathrm{Fe}^{3+}$ & 0.42 & 0.06 & 0.47 & 0.12 & 0.52 & 0.08 & 0.75 & 0.38 & 0.76 & 0.06 & 0.44 & 0.02 \\
\hline $\mathrm{Mg}$ & 1.21 & 0.06 & 1.21 & 0.19 & 1.22 & 0.08 & 1.44 & 0.19 & 1.54 & 0.13 & 1.29 & 0.07 \\
\hline$\Sigma$ cations & 4.26 & 0.05 & 4.21 & 0.11 & 4.30 & 0.05 & 4.40 & 0.11 & 4.35 & 0.08 & 4.29 & 0.08 \\
\hline \multicolumn{13}{|l|}{ Interiayer cations } \\
\hline $\mathrm{Ca}$ & 0.16 & 0.02 & 0.16 & 0.05 & 0.13 & 0.03 & 0.17 & 0.07 & 0.24 & 0.09 & 0.08 & 0.07 \\
\hline K & 0.07 & 0.01 & 0.22 & 0.10 & 0.05 & 0.02 & 0.12 & 0.06 & 0.09 & 0.16 & 0.06 & 0.05 \\
\hline $\mathrm{Na}$ & 0.15 & 0.04 & 0.12 & 0.15 & 0.18 & 0.05 & 0.01 & 0.04 & 0.19 & 0.16 & 0.27 & 0.20 \\
\hline Interlayer charge & 0.54 & 0.07 & 0.65 & 0.13 & 0.48 & 0.08 & 0.30 & 0.10 & 0.73 & 0.25 & 0.49 & 0.24 \\
\hline
\end{tabular}

$n$ : number of analysed spots in each sample; sd: standard deviation.

Table 3

Average chemical composition (TEM + EDX analyses) and structural formulae of the smectites from mass flow unit.

\begin{tabular}{|c|c|c|c|c|c|c|c|c|c|c|}
\hline \multirow[t]{2}{*}{ wt\% } & \multicolumn{2}{|c|}{ B1-M5 $(n=15)$} & \multicolumn{2}{|c|}{ B2-M3 $(n=11)$} & \multicolumn{2}{|c|}{ B3-M1 $(n=11)$} & \multicolumn{2}{|c|}{ B3-M2 $(n=11)$} & \multicolumn{2}{|c|}{ B4-M3 $(n=9)$} \\
\hline & Mean & so & Mean & 30 & Mean & 34 & Mean & st & Mean & 30 \\
\hline $\mathrm{SiO}_{2}$ & 56.16 & 4.08 & 61.17 & 1.50 & 62.31 & 1.38 & 61.14 & 1.49 & 63.9 & 1.38 \\
\hline $\mathrm{Al}_{2} \mathrm{O}_{3}$ & 23.60 & 2.18 & 18.35 & 1.00 & 16.61 & 1.58 & 16.83 & 1.44 & 17.58 & 0.57 \\
\hline $\mathrm{Fe}_{2} \mathrm{O}_{3}$ & 8.14 & 2.91 & 9.08 & 1.31 & 9.67 & 1.39 & 9.41 & 1.55 & 7.76 & 0.62 \\
\hline $\mathrm{MgO}$ & 9.33 & 2.52 & 8.19 & 1.05 & 9.36 & 1.67 & 8.64 & 0.80 & 8.78 & 0.80 \\
\hline $\mathrm{K}_{2} \mathrm{O}$ & 1.25 & 0.56 & 0.5 & 0.20 & 0.51 & 0.25 & 1.52 & 0.52 & 0.58 & 0.23 \\
\hline $\mathrm{CaO}$ & 0.80 & 0.34 & 2.12 & 0.99 & 1.55 & 0.40 & 1.8 & 0.37 & 1.13 & 0.18 \\
\hline $\mathrm{Na}_{2} \mathrm{O}$ & 0.81 & 0.31 & 0.67 & 0.14 & 0.22 & 0.37 & 0.54 & 0.41 & 0.19 & 0.29 \\
\hline \multicolumn{11}{|c|}{$\begin{array}{l}\text { Numbers of cations on the basis of } \mathrm{O}_{2}(\mathrm{OH})_{4} \\
\text { Tetrahedral cations }\end{array}$} \\
\hline $\mathrm{Si}$ & 6.87 & 0.39 & 7.46 & 0.13 & 7.57 & 0.10 & 7.52 & 0.15 & 7.70 & 0.13 \\
\hline $\mathrm{Al}^{\mathrm{IV}}$ & 1.13 & 0.39 & 0.54 & 0.13 & 0.43 & 0.10 & 0.48 & 0.15 & 0.30 & 0.13 \\
\hline \multicolumn{11}{|l|}{ Octahedral cations } \\
\hline $\mathrm{Al}^{\mathrm{VI}}$ & 2.28 & 0.47 & 2.09 & 0.19 & 1.95 & 0.27 & 1.96 & 0.20 & 2.20 & 0.13 \\
\hline $\mathrm{Fe}^{3+}$ & 0.75 & 0.28 & 0.85 & 0.12 & 0.90 & 0.13 & 0.87 & 0.15 & 0.71 & 0.06 \\
\hline $\mathrm{Mg}$ & 1.71 & 0.49 & 1.49 & 0.20 & 1.74 & 0.26 & 1.58 & 0.15 & 1.58 & 0.15 \\
\hline$\Sigma$ cations & 4.75 & 0.31 & 4.43 & 0.14 & 4.53 & 0.16 & 4.41 & 0.11 & 4.49 & 0.07 \\
\hline \multicolumn{11}{|l|}{ Interiayer cations } \\
\hline $\mathrm{Ca}$ & 0.10 & 0.04 & 0.27 & 0.14 & 0.20 & 0.05 & 0.24 & 0.05 & 0.15 & 0.02 \\
\hline K & 0.20 & 0.09 & 0.07 & 0.03 & 0.08 & 0.04 & 0.24 & 0.08 & 0.09 & 0.03 \\
\hline $\mathrm{Na}$ & 0.19 & 0.07 & 0.15 & 0.03 & 0.05 & 0.09 & 0.13 & 0.10 & 0.04 & 0.07 \\
\hline Interlayer charge & 0.60 & 0.15 & 0.75 & 0.30 & 0.53 & 0.12 & 0.85 & 0.18 & 0.43 & 0.11 \\
\hline
\end{tabular}

$n$ : number of analysed spots in each sample; sd: standard deviation.

would indicate that the relative abundance of $\mathrm{Fe}$ is the controlling factor for the compositional variations of these smectites (Christidis and Dunham, 1997). From both diagrams the separation into two clear populations is observed, which corresponds to the two groups of studied smectites: smectites from white tuffs unit, which have a higher content of $\mathrm{Al}^{\mathrm{VI}}$, and smectites from the mass flow unit, which have higher contents of $\mathrm{Fe}_{2} \mathrm{O}_{3}$ and $\mathrm{MgO}$.

The Al-Fe-Mg ternary diagram (Fig. 8A) clearly shows that smectites from the white tuffs unit are grouped closer to the $\mathrm{Al}$ vertex than smectites from the mass flow. A similar plot of the smectites from white tuffs is observed in those from acid precursor rocks studied by Christidis and Dunham (1997). In comparison, smectites from the mass flow unit show higher compositional dispersion toward the $\mathrm{Mg}$ and Fe vertices, displaying a scheme similar to that described by Christidis and Dunham (1993) in smectites from the alteration of intermediate volcanic rocks from Milos Island (Greece). This ternary diagram (Fig. 8A) has been compared with that shown in Pérez del Villar et al. (2003, 2005) (Fig. 8B), observing that smectites from the white tuffs plot in the field occupied by the smectites located far from the Morrón de Mateo 



Fig. 7. Relationship between $\mathrm{Al}^{\mathrm{VI}}$ and $\mathrm{Fe}^{3+}(\mathrm{A})$ and between $\mathrm{Al}^{\mathrm{VI}}$ and $\mathrm{Mg}(\mathrm{B})$ for all of the studied smectites where the trend line and correlation coefficient for smectites from mass flow and white tuffs unit are shown.

volcanic dome, while smectites from the mass flow unit plot in the field occupied by smectites from the proximal zones of the volcanic dome.

Smectites are also plotted on the $M R^{3}-2 R^{3}-3 R^{2}$ ternary diagram proposed by Velde (1985) (Fig. 9). It shows that smectites from white tuffs develop a variation along the $2 R^{3}-M R^{3}$ trend, having a $3 \mathrm{R}^{2}$ component which is almost stable, indicating that in these smectites the total interlayer charge is variable, but not their di or trioctahedral character. Smectites from the mass flow unit show a higher dispersion along the $2 \mathrm{R}^{3}-\mathrm{MR}^{3}$ direction and, therefore, a higher variability in the interlayer charge. They show a variation toward the $3 R^{2}$ axis, indicating a moderate variation of their di or trioctahedral character. They have a $3 R^{2}$ component higher than smectites from the white tuffs unit, indicating a higher trioctahedral character. This data corroborate the XRD patterns of mass flow smectites, where trioctahedral and dioctahedral smectites coexist.

When the structural formulae are plotted on the muscovite-celadonite-pyrophyllite ternary diagram proposed by Newman and Brown (1987) (Fig. 10A), a greater dispersion is also observed in smectites from the mass flow unit than in smectites from white tuffs. Smectites from the white tuffs unit plot in the smectite domain with an interlayer charge below 1.0, their charge being mainly due to the octahedral substitutions. However, the charge of smectites from the mass flow unit is caused by both octahedral and tetrahedral substitutions, dominated by the tetrahedral ones. The particles plotted with an interlayer charge higher than 1, possibly correspond to the interstratified clay minerals. If this diagram is compared with that from Pérez del Villar et al. $(2003,2005)$ (Fig. 10B), it is observed that smectites from the white tuffs fall in the field occupied by smectites from distal zones, while smectites from the mass flow unit plot in the field of smectites from the white tuffs located close to the volcanic dome, as occurs in the octahedral cations ternary diagram.
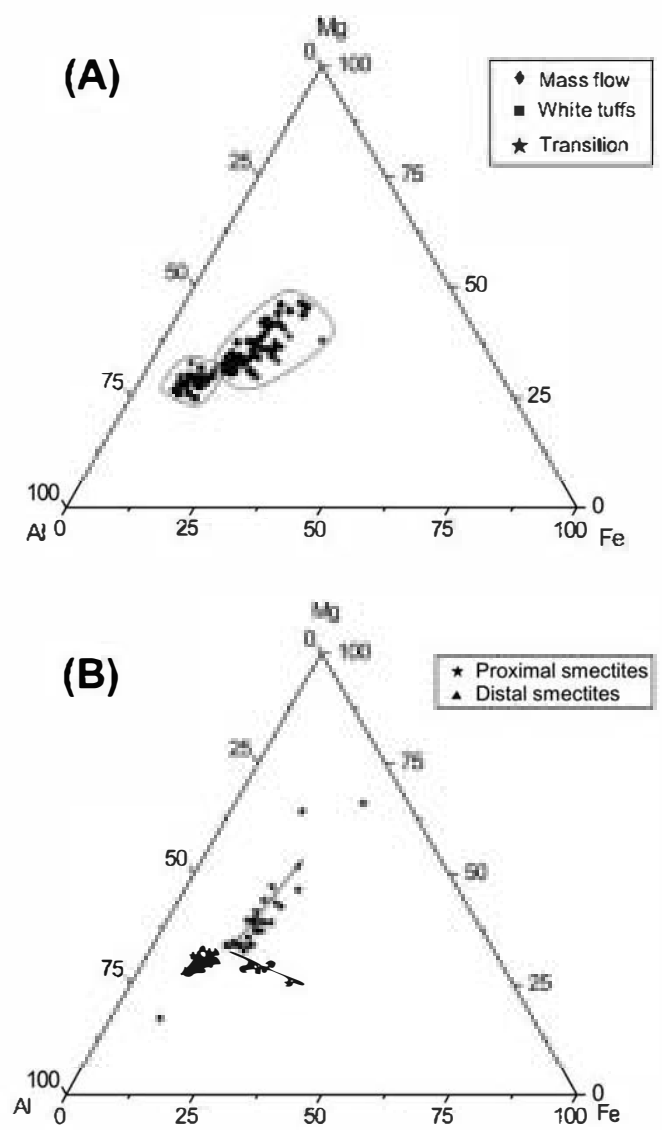

Fig. 8. Fe-Mg-Al ternary diagram on which the octahedral cations of the smectites are plotted. (A) Smectites from this study. (B) Proximal and distal smectites from the Morrón de Mateo volcanic dome (Pêrez del Villar et aI., 2003, 2005). The dashed lines in figure $(A)$ indicate the two smectite populations.



Fig. 9. Crystal-chemical formulae of the smectites plotted on the $M R^{3}-2 R^{3}-3 R^{2}$ ternary diagram proposed by Velde $(1985)$. $\left(\mathrm{MR}^{3}=\mathrm{Na}+\mathrm{K}+2 \mathrm{Ca} ; 2 \mathrm{R}^{3}=\left(\mathrm{AI}+\mathrm{Fe}^{3+}-\right.\right.$ $\left.\left.\mathrm{MR}^{3}\right) / 2 ; 3 \mathrm{R}^{2}=\left(\mathrm{Mg}+\mathrm{Fe}^{2+}\right) / 3\right)$. Notice the separation into two smectite populations and a higher dispersion in smectites from the mass flow unit.

The fact that smectites from white tuffs located close to the dome (Pérez del Villar et al., 2003, 2005) show crystal-chemical features similar to those from the mass flow unit (analysed in this study), might be explained taking into account the hypothesis that smectites close to the dome were affected by hydrothermal solutions related to the intrusion of the dome, which supplied Fe and $\mathrm{Mg}$ to transform Al-rich smectites into Fe-Mg-rich ones, as reported in Pérez del Villar et al. $(2003,2005)$. The hydrothermal 


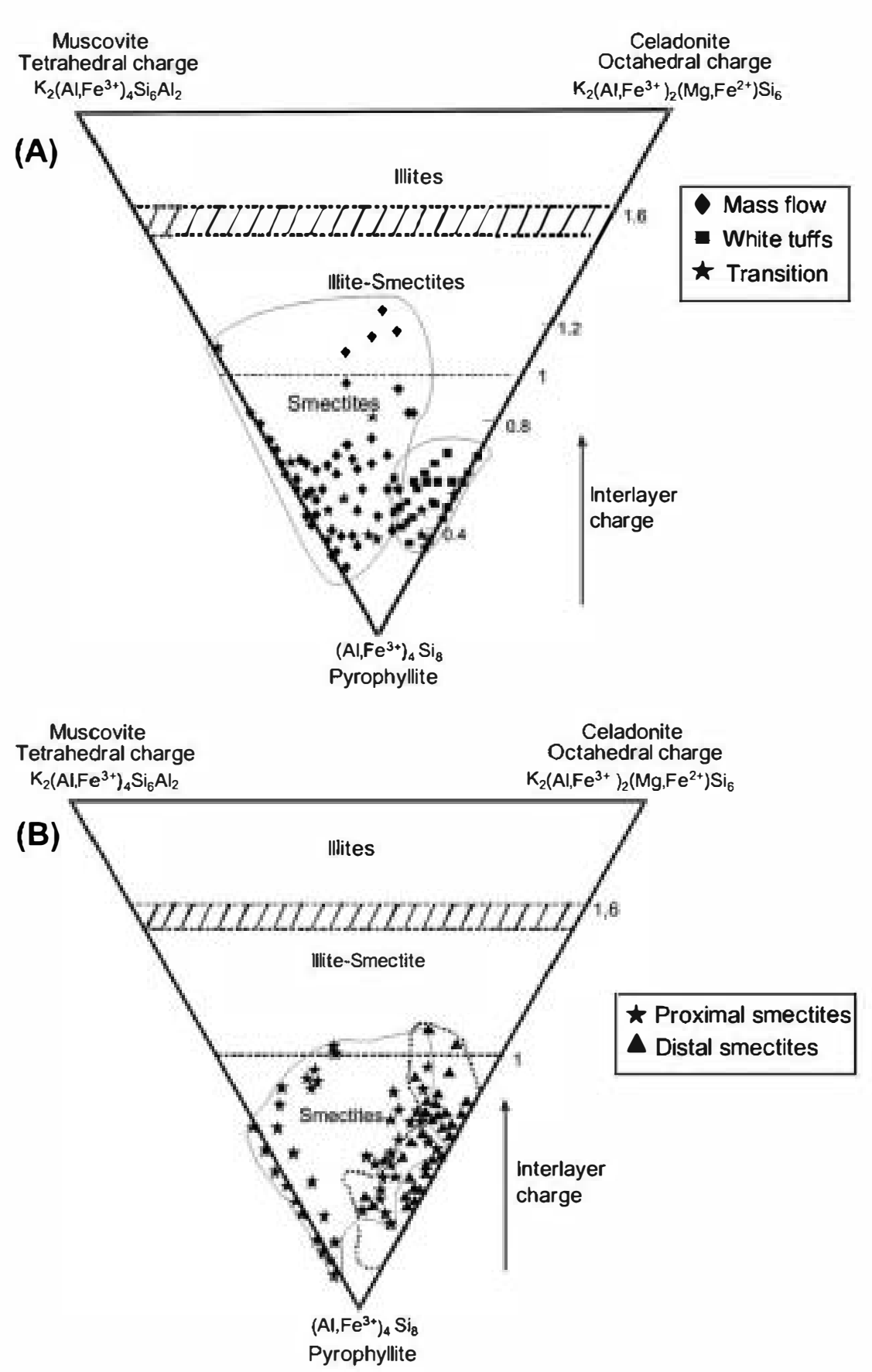

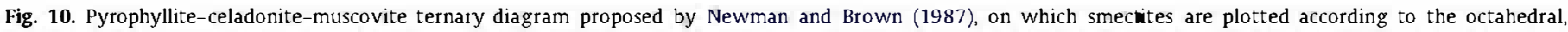

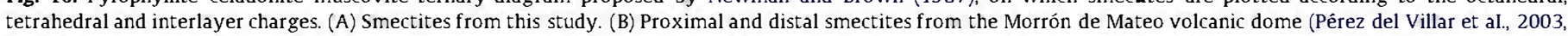
2005).

process could have been more intensive toward the south slope of the "Los Escullos" basin, due to its geometry (see Fig. 1), mainly affecting smectites located close to the Morrón de Mateo dome.

\subsubsection{Corrensite}

In order to determine the chemical and textural features of corrensite, samples from the mass flow formation have been studied. Analyses were carried out by SEM + EDX on fragments and polished thin-sections. The chemical composition and structural formulae are shown in Table 4. The structural formulae are based on $\mathrm{O}_{40}(\mathrm{OH})_{20}$ (Beaufort and Meunier, 1994; Newman and Brown, 1987). In this table, data for corrensite from Inoue and Utada (1991) have also been given for comparison. Thus, the chemical composition of the corrensite-like clay mineral from sample B1-
M5 is similar to that obtained by the abovementioned authors (Fig. $11 \mathrm{~A}$ and B). The remaining samples (Figs. 12A-D and $13 \mathrm{~A}$ and $B$ ) have a slightly different chemical composition from those reported by Inoue and Utada (1991). These differences could be due to chemical variations in the corrensite composition and/or to the semi-quantitative character of this analytical method. In any case, all the analytical data can be considered as belonging to corrensite-like clay minerals. The compositional variability is more evident in the octahedral than in tetrahedral coordination. Since, the number of $\mathrm{Mg}$ atoms varies between $44 \%$ and $59 \%$ in the octahedral sites, while the number of atoms of Al varies between $15 \%$ and $21 \%$ in the tetrahedral ones. These characteristics agree with a corrensite-type clay mineral (Brigatti and Poppi, 1984). Furthermore, the number of octahedral cations ranges from 
Table 4

Average chemical composition (SEM + EDX) and structural formulae of the corrensite-like clay minerals.

\begin{tabular}{|c|c|c|c|c|c|c|c|}
\hline \multirow[t]{2}{*}{ Wt\% } & \multicolumn{2}{|l|}{ B1-M3 } & \multirow{2}{*}{$\begin{array}{l}\text { B1-M5 } \\
\text { Point } 1\end{array}$} & \multicolumn{2}{|l|}{ B5-M4 } & \multicolumn{2}{|c|}{ (Inoue and Utada, 1991) } \\
\hline & Point 1 & Point 2 & & Point 1 & Point 2 & $18-360$ & $16-60$ \\
\hline $\mathrm{SiO}_{2}$ & 43.73 & 43.75 & 39.49 & 42.39 & 44.55 & $39.42^{a}$ & $36.83^{a}$ \\
\hline $\mathrm{Al}_{2} \mathrm{O}_{3}$ & 19.23 & 18.27 & 17.98 & 16.96 & 15.26 & 15.54 & 17.89 \\
\hline $\mathrm{FeO}$ & 18.11 & 18.00 & 25.13 & 19.11 & 15.87 & 19.21 & 23.40 \\
\hline $\mathrm{MgO}$ & 17.97 & 18.74 & 16.41 & 19.37 & 22.39 & 24.54 & 20.44 \\
\hline $\mathrm{K}_{2} \mathrm{O}$ & - & 0.91 & - & 0.14 & 0.16 & - & 0.05 \\
\hline $\mathrm{CaO}$ & 0.95 & 0.33 & 0.42 & 2.02 & 1.64 & 0.90 & 1.33 \\
\hline $\mathrm{Na}_{2} \mathrm{O}$ & - & - & - & - & - & - & - \\
\hline $\mathrm{MnO}$ & 0.35 & - & 0.57 & - & * & 0.40 & 0.09 \\
\hline \multicolumn{8}{|c|}{$\begin{array}{l}\text { Numbers of cations on the basis of } \mathrm{O}_{4 \bullet}(\mathrm{OH})_{2} \\
\text { Tetrahedral cations }\end{array}$} \\
\hline $\mathrm{Si}$ & 13.30 & 13.37 & 12.57 & 13.10 & 13.54 & 12.30 & 11.75 \\
\hline $\mathrm{Al}^{\mathrm{IV}}$ & 2.70 & 2.63 & 3.43 & 2.90 & 2.46 & 3.70 & 4.25 \\
\hline \multicolumn{8}{|l|}{ Octahedral cations } \\
\hline $\mathrm{Al}^{\mathrm{VI}}$ & 4.20 & 3.94 & 3.31 & 3.27 & 3.00 & 2.02 & 2.47 \\
\hline $\mathrm{Fe}^{2+}$ & 4.60 & 4.59 & 6.67 & 4.93 & 4.02 & 5.00 & 6.23 \\
\hline $\mathrm{Mg}$ & 8.14 & 8.53 & 7.78 & 8.92 & 10.13 & 11.41 & 9.71 \\
\hline$\Sigma$ cations & 16.94 & 17.06 & 17.77 & 17.12 & 17.16 & 18.44 & 18.41 \\
\hline $\mathrm{Fe} /(\mathrm{Fe}+\mathrm{Mg})$ & 0.36 & 0.35 & 0.46 & 0.36 & 0.28 & 0.305 & 0.391 \\
\hline \multicolumn{8}{|l|}{ Interlayer cations } \\
\hline $\mathrm{Ca}$ & 0.31 & 0.11 & 0.14 & 0.67 & 0.53 & 0.30 & 0.44 \\
\hline $\mathrm{K}$ & - & 0.35 & - & 0.06 & 0.06 & - & - \\
\hline $\mathrm{Na}$ & - & - & - & - & - & - & - \\
\hline $\mathrm{Mn}$ & 0.09 & - & 0.14 & - & - & 0.14 & 0.02 \\
\hline Interlayer charge & 0.80 & 0.57 & 0.57 & 1.39 & 1.13 & 0.88 & 0.95 \\
\hline
\end{tabular}

a These data have been normalised to $100 \%$ in order to make the appropriate comparisons.
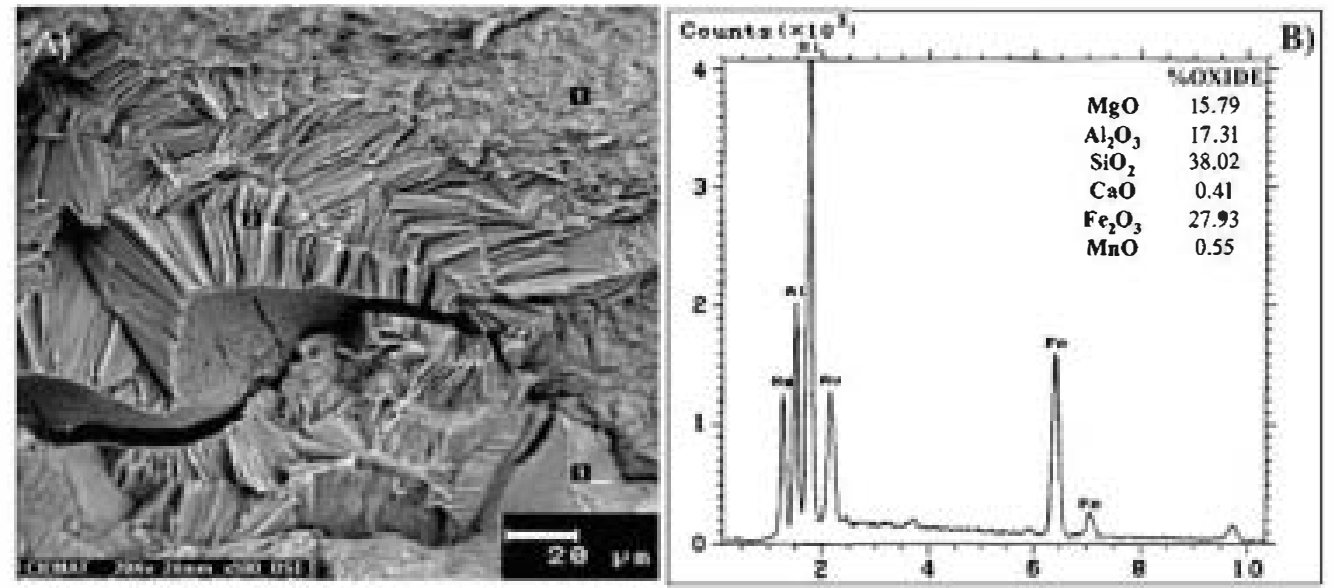

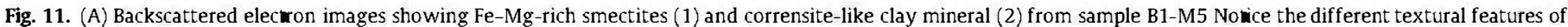
both clay minerals and the close relationship between them. (B) EDX specrum of the probably corrensite ( 2 in image A).

16.94 to 17.77 p.u.c., being 18 octahedral cations per $\mathrm{O}_{40}(\mathrm{OH})_{20}$ for an ideal corrensite. On the other hand, corrensite from Morrón de Mateo has a $\mathrm{Fe} /(\mathrm{Fe}+\mathrm{Mg})$ ratio ranging from 0.28 to 0.46 , which is in the range of values obtained by Inoue and Utada (1991) (see Table 4). Iron/(Fe $+\mathrm{Mg}$ ) values higher than 0.5 indicate that this clay mineral would be chlorite (Brigatti and Poppi, 1984).

As mentioned above, the textural features of corrensite in relation to Fe-Mg-rich smectites (Figs. 12A and 13A) indicate that the corrensite-like clay mineral probably formed from $\mathrm{Fe}-\mathrm{Mg}$-rich smectites. This suggestion seems to be confirmed by the chemical analyses obtained from points 1,2 and 3 in Figs. 12A-D that show the chemical variations from an Al-rich smectite to a corrensitelike clay mineral passing through a Fe-Mg rich smectite.

The presence of secondary corrensite in samples from the mass flow unit and, specially, in those intersected by borehole 1, which is closer to the dome, would be in agreement with the hypothesis reported in Section 4.2.1. This hypothesis argues that the Fe$\mathrm{Mg}$-rich smectites located close to the dome, are the result of an interaction process between the original Al-rich smectites and hydrothermal solutions related to the intrusion of the dome, which supplied $\mathrm{Fe}$ and $\mathrm{Mg}$, and the original Al-smectites were transformed into Fe-Mg-rich ones. Similarly, Fe-Mg rich smectites from the mass flow unit could also have been affected by the same interaction process resulting in the corrensite-like clay mineral. However, a transformation process from Al-rich smectites to $\mathrm{Fe}-$ $\mathrm{Mg}$-rich smectites and the corrensite like-mineral as end members cannot be discarded.

In support of this, Bril et al. (1996), Chang et al. (1986), Hoffman and Hower (1979), Inoue (1985), Inoue et al. (1984), Liou et al. (1985) and Robinson and Santana de Zamora (1999) reported that 

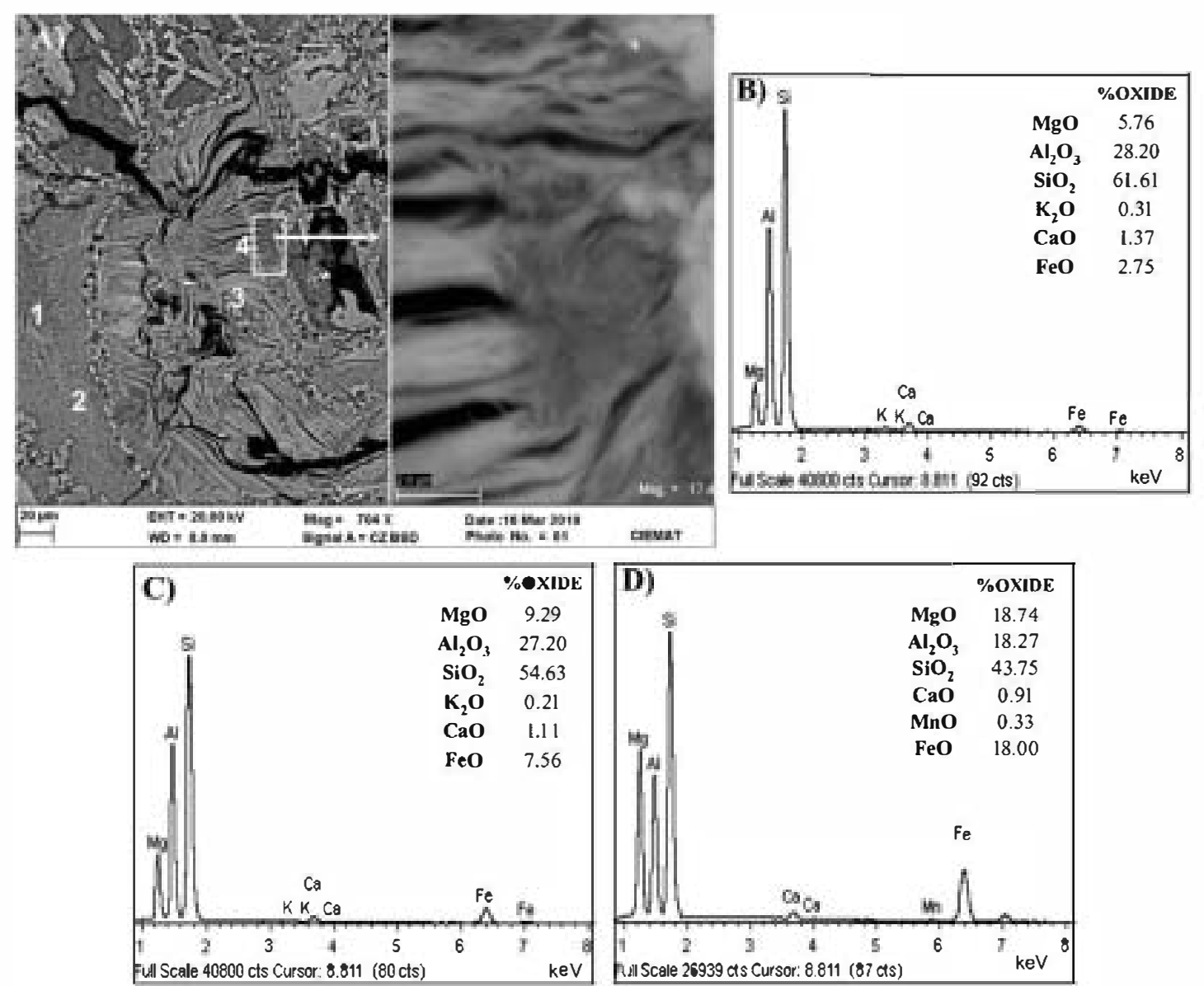

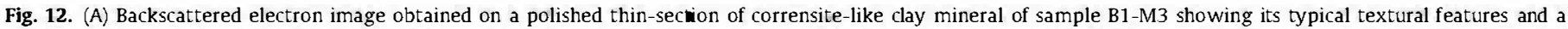

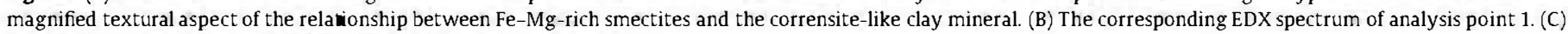
EDX spectrum of analysis point 2. (D) EDX specum of analysis point 3.
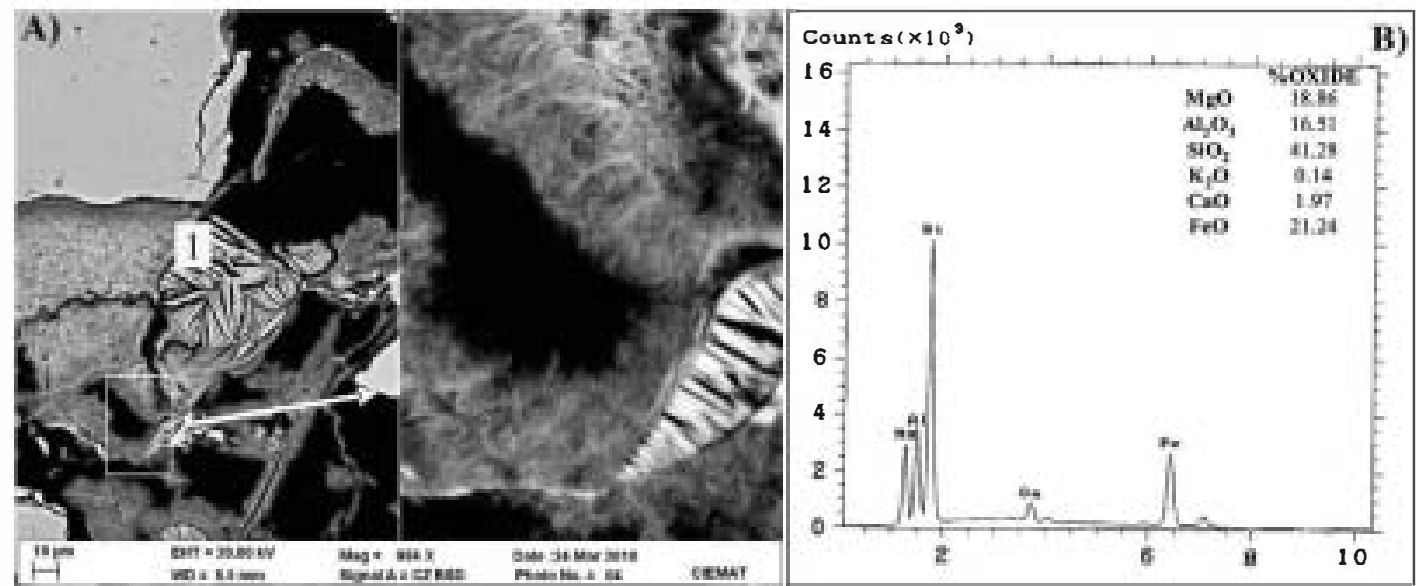

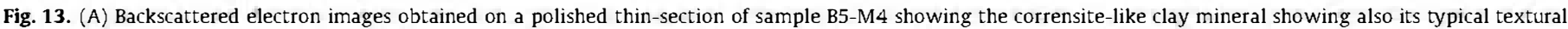

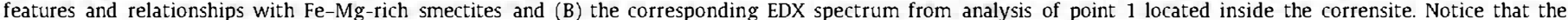
corrensite-like mineral comes from the transformation of $\mathrm{Fe}-\mathrm{Mg}$-rich smectites.

corrensite usually occurs as an intermediate product in the saponite-chlorite transformation process, as temperature increases. In order to explain this transformation process, two theories have been reported. The first considers that this conversion involves a continuous sequence of interstratified chlorite/smectite phases, with an increasing proportion of chloritic layers as alteration pro- ceeds, reaching chlorite as a stable end member mineral phase (Liou et al., 1985; Robinson et al., 1993). The second theory involves a discontinuous sequence with steps from smectite to corrensite and from corrensite to chlorite without any continuous sequence of mixed-layering (Schmidt and Robinson, 1997). Inoue and Utada (1991) studied corrensite in Miocene volcanoclastic 
rocks from Kamikita (Japan), concluding that this mineral was formed at temperature between 100 and $200{ }^{\circ} \mathrm{C}$ induced by an intensive thermal metamorphic episode, related to a hornblendic quartz-diorite intrusion. These authors suggested that this clay mineral would be an intermediate step of the saponite to chlorite transformation process. This process could be analogous to that observed in the mass flow unit surrounding the Morrón de Mateo dome.

Therefore, it is suggested that the volcanoclastic rocks, both the white tuffs and mass flow units, in the site were firstly transformed into Al-rich smectites or Fe-Mg-rich smectites depending on the nature of the parent rocks. Later on, the intrusion of the volcanic dome provoked a transformation process induced by the hydrothermal $\mathrm{Fe}-\mathrm{Mg}$ rich fluids, transforming Al-rich smectites into Fe-Mg-rich smectites, and the Fe-Mg-rich smectites into an ordered (R1) chlorite/smectite interstratified (corrensite). This last process was more intensive in samples from borehole 1 , since it is closer to the volcanic dome and, therefore, more exposed to the hydrothermal solutions responsible for the transformation process.

The important facts to consider in transformation processes from Al-rich smectites to Fe-Mg-rich smectites and corrensite like-minerals as end members, are the following: (i) the presence of the $\mathrm{Fe}, \mathrm{Mg}$ and $\mathrm{Mn}$ metasomatized biocalcarenites close to the dome (Delgado, 1993; Pérez del Villar et al., 2003, 2005); (ii) the temperatures calculated from stable isotope $\left(\delta^{18} \mathrm{O}\right.$ and $\left.\delta^{2} \mathrm{H}\right)$ data for smectites located close to the Morrón de Mateo dome, between 55 and $66^{\circ} \mathrm{C}$, (Pérez del Villar et al., 2003, 2005) and in smectites located just in contact with the dome, between $75^{\circ} \mathrm{C}$ and $95^{\circ} \mathrm{C}$ (Delgado, 1993; Delgado and Reyes, 1993); (iii) the temperature obtained for proximal secondary calcite, dolomite and siderite in metasomatized biocalcarenite, between $28^{\circ} \mathrm{C}$ and $90^{\circ} \mathrm{C}$; and (iv) the formation of abundant corrensite in samples of the mass flow unit intersected by the borehole closer to the dome. However, future studies are envisaged in order to clarify all the alteration processes involved in the site in relation to the intrusion of the volcanic dome.

In summary, all these data suggest that the Morrón de Mateo natural system is a good natural analogue of the thermal and chemical effects on the engineered clayey barrier of a deep geological HLRW repository after burial. Both effects, temperature and chemical environment, would be related to the radioactive waste decay and to the degradation of the waste canister, respectively, that in the past Spanish conceptual model would be constituted by carbon steel. Thus, under these probable conditions, the candidate bentonite mainly formed by Al-rich smectites would transform into Fe-Mg-rich smectites and corrensite, as intermediate steps to chlorite. In this case, all the physicochemical and mechanical properties of Al-rich smectites would disappear and the role clayey barrier would fail (Pérez del Villar et al., 2003, 2005).

Finally, the laboratory experiments performed in order to study the stability of the bentonite barrier due to the interaction with the canister corrosion products, mainly $\mathrm{Fe}$, and their thermodynamic simulations, indicate that smectite in the presence of Fe-oxides at $80^{\circ} \mathrm{C}$ is stable at the time scale of the experiments (Guillaume et al., 2004), while at $300^{\circ} \mathrm{C}$ mineralogical changes occurred, such as the formation of Fe saponite, quartz, feldspar and zeolite. In addition, experiments in the presence of metallic $\mathrm{Fe}$ at $300^{\circ} \mathrm{C}$ (Guillaume et al., 2003) showed the formation of saponite, chlorite, feldspars, quartz and zeolites. However, the presence of interstratified clays in these experiments is scarce. According to the above mentioned authors, this is probably due to the experimental temperature $\left(300^{\circ} \mathrm{C}\right)$, which is sufficiently high to prevent the formation of interstratified chlorite-smectite minerals, as an intermediate step, as occurs in the Morrón de Mateo site.
Furthermore, the experiments carried out by Wilson et al. (2006) on the stability of bentonite in the presence of native $\mathrm{Fe}$, magnetite and aqueous solutions under hydrothermal conditions and different chemical, thermodynamic conditions and reaction times, showed that native Fe was oxidised to produce magnetite and the starting Na-montmorillonite was transformed into Fe-rich smectites, only when Fe was added as a metal rather than magnetite. However, at $250^{\circ} \mathrm{C}$ the neo-formation of a small amount of a $1: 1$ non expandable sheet silicate was observed, probably a berthierine-like mineral (chamosite), belonging to the serpentine subgroup, according to the Newman and Brown (1987) clay classification.

However, it is noticeable that, in these experiments, the reaction time is substituted by a very important increase of reaction temperature resulting in the direct formation of non expandable sheet minerals. By contrast, in the natural analogue system of Morrón de Mateo interlayer and expandable minerals occur due to the temperature reached in the site being lower than in the laboratory experiments, but the reaction time was much longer than in the above mentioned laboratory experiments.

\section{Conclusions}

1. The mineralogical composition of bentonites of the Morrón de Mateo deposit seems to be mainly conditioned by the composition of the two parent lithological units differentiated in the studied zone. The white tuffs unit has higher phyllosilicate content. They are mainly smectite of montmorillonite type with a quite homogeneous chemical composition and a higher $\mathrm{SiO}_{2}$ and $\mathrm{Al}_{2} \mathrm{O}_{3}$ contents than smectites from the mass flow unit, as a consequence they are derived from acidic volcanic rocks. Samples from the mass flow unit have a higher proportion of inherited minerals, the neoformed phyllosilicates being mainly beidellites, minor intermediate clay mineral between beidellite and saponite and corrensite. Smectites show more chemical variability, containing higher $\mathrm{Fe}_{2} \mathrm{O}_{3}$ and $\mathrm{MgO}$ as a consequence of the epiclastic parent rocks, mainly constituted of fragments of intermediate volcanic rocks.

2. The presence of corrensite in samples from the mass flow unit is remarkable, since it is the first time that this clay mineral has been cited in the bentonite deposits from the Cabo de Gata volcanic region. Though it has only been detected by using $\mathrm{X}$-ray diffraction in samples intersected by borehole 1 , it has been identified by SEM + EDX in all the samples from the mass flow unit.

3. The existence of corrensite in the samples from the mass flow unit suggests that in the Morrón de Mateo area a hydrothermal alteration process occurred after the bentonitization process, which was responsible for the transformation of Fe-Mg rich smectites into corrensite. This transformation was probably favoured by the sub-volcanic intrusion of the Morrón de Mateo dome, which produced an increase of temperature in the area and a supply of Fe-Mg-rich hydrothermal solutions. This process was also responsible for the metasomatic transformations observed by other authors in the biocalcarenite beds overlaying the bentonite deposit and the transformation of Al-smectite close to the volcanic dome into Fe-Mg-rich smectite.

4. All these data suggest that the Morrón de Mateo natural system could be a good natural analogue of the thermal and chemical effects on the bentonite barrier of a geological HLRW repository. In this man-made system the thermal effect would be related to the radioactive decay of fission products and the chemical effects could be related to the canister corrosion products and water intrusion in the storage system. These undesirable circumstances would favour the transformation of the candidate 
Al-rich smectites into Fe-Mg-rich smectites and corrensite, as intermediate steps to form chlorite. In this case, all the physicochemical and mechanical properties of Al-rich smectites would disappear and the clayey barrier would fail.

5. The laboratory experiments performed to study the stability of the bentonite barrier are very similar to the field results obtained, since smectite in the presence of Fe oxides and metallic $\mathrm{Fe}$ at $300^{\circ} \mathrm{C}$ resulted in the formation of $\mathrm{Fe}$ saponite, different types of chlorites and minor mixed-layered clays, respectively. Interstratified chlorite-smectite minerals were scarce in the laboratory work because the temperature reached in these experiments was sufficiently high to reduce the formation of these interstratified clays. In contrast, in the natural analogue system of Morrón de Mateo interlayer clay minerals occur, since the temperature reached in the site, between 70 and $90^{\circ} \mathrm{C}$, was lower than in the laboratory experiments and the reaction time was much longer than in the experiments.

\section{Acknowledgements}

Financial support for this work has been provided by CIEMAT (Spain) through the project: analogue processes of the clayey barrier behaviour in the Cabo de Gata bentonite deposits (Almería, SE Spain). The authors are grateful to D. Tejela from Süd-Chemie, Spain S.L. for providing the drillcore samples. We would also like to thank to R. Saldaña for the preparation of the samples, L. Gutierrez-Nebot for the XRD determinations and A. Gómez-Herrero for the TEM analyses. We also thank $\mathbf{B}$. Hartley for reviewing the English; Dr. R. Pusch and another anonymous reviewer for their suggestions and comments that improved the manuscript.

\section{References}

Abad, I., Jimênez-Millán, J., Molina, J.M., Nieto, F., Vera, J.A., 2003. Anomalous reverse zoning of saponite and corrensite caused by contact metamorphism and hydrothermal alteration of marly rocks associated with subvolcanic bodies. Clays Clay Miner. 51 (5), 543-554

Alt,J.C., Honnorez, J., Laverne, Emmermann, R., 1986. Hydrothermal alteration of a 1 $\mathrm{km}$ section through the upper oceanic crust, DSDP Hole 504B: mineralogy chemisty, and evolution of seawater-basalt interactions. J. Geophys. Res. 91 10309-10335.

April, R.H., 1981. Trioctahedral smectite and interstratified chlorite smectite in Jurassic strata of the Connecticut Valley. Clays Clay Miner. 29, 31-39.

Arribas Jr., A., 1993. Mapa geológico del diswito minero de Rodalquilar, Almería. Instituto Tecnológico Geominero de España. Madrid.

Arribas Jr., A., Cunningham, C.G., Rytuba, J.J., Rye, R.O., Podwysocki, M.H., Mckee, E.H., TosdaI, R.M., 1995. Geology, geochronology, fluid inclusions and isotope geochemistry of the Rodalquilar gold alunite deposit, Spain. Econ. Geol. 90, 795-822.

Barahona, E., 1974. Arcillas de ladrillería de la provincia de Granada: evaluación de algunos ensayos de materias primas. Ph.D. Thesis, Univ. Granada, Spain.

Beaufort, D., Meunier, A., 1994. Saponite, corrensite and chlorite/saponite mixed layered minerals and saponite in the Sancerre-Couy deep drill hole (France). Clay Miner. 29, 47-61.

Beaufort, D., Baronnet, A., Lanson, B., Meunier, A., 1997. Corrensite: a single phase or a interstratified phyllosilicate in the saponite-to-chlorite conversion series? A case study of Sancerre-Couy deep drill hole (France). Am. Mineral. 82, 109-124.

Bergaya, F., Brigati, M.F., Fripiat, J.J., 1985. Contribution of infrared spectroscopy to the study of corrensite. Clays Clay Miner. 33 (5), 458-462.

Betzler, C., Brachert, T.C., Braga, J.C., Martín, J.M., 1997. Near-shore, temperate, carbonate depositional systems (Lower Tortonian, Agua Amarga Basin, southern Spain): implications for carbonate sequence stratigraphy. Sediment. Geol. 113 27-53.

Bordet, P., 1985. Le volcanisme miocène des Sierras de Gata et de Carboneras (Espagne du Sud-Est). Doc. et Trav. IGAL, Paris 8.

Bradley, W.F., Grim, R.E., 1961. Mica clay minerals. In: Brown, G. (Ed.), The X-ray Identification and Crystal Swucture of Clay Minerals. Mineralogical Society London, pp. 208-241.

Brigati, M.F., Poppi, L., 1984. Crystal chemistry of corrensite: a review. Clays Clay Miner. 32, 391-399

Bril, H., Papapanagiotou, P., Patrier, P., Lenain, J.F., Beaufort, D., 1996. Fluid-rock interaction in the geothermal field of Chipilapa (El Salvador): contribution of fluid-inclusion data. Eur. J. Mineral. 8, 515-531 uatier, M.D., Früh-Green, G.L., Karpoff, A.M., 1995. Mechanisms of MgPhyllosilicate formation in a hydrothermal system at a sedimented ridge (Middle Valley, Juan de Fuca). Contrib. Mineral. Petrol. 122, 134-151.

Caballero, E., Reyes, E., Yusta, A., Huertas, F., Iinares, J., 1985. Las bentonitas de la zona sur de Cabo de Gata, Almería. Geoquímica y mineralogía. Acta Geol. Hispánica 20, 267-287.

Chang, H.K., Mackenzie, F.T., Schoonmaker, J., 1986. Comparisons between the diagenesis of dioctahedral and trioctahedral smectite Brazilian off fhore basins. Clays Clay Miner. 34, 407-423.

Christidis, G., Dunham, A.C., 1993. Compositional variations in smectites. Part I. Alteration of intermediate volcanic rocks. A case study from Milos Island, Greece. Clay Miner. 28, 255-273.

Christidis, G., Dunham, A.C., 1997. Compositional variations in smectites. Part II. Alteration of acidic precursors, a case study from Milos Island, Greece. Clay Miner. 32, 253-270.

Cunningham, C.G., Arribas, J.R.A., Rytuba, J.J., Arribas, A., 1990. Mineralized and unmineralized calderas in Spain; Part I, evolution of the Los Frailes Caldera. Mineral. Depos. 25, S21-S22.

Delgado, A., 1993. Estudio isotópico de los procesos diagenéticos e hidrotermales relacionados con la gênesis de bentonitas (Cabo de Gata, Almería). Ph.D. Thesis, CSIC, Granada, Spain

Delgado, A., Reyes, E., 1993. Isotopic study of the diagenetic and hydrothermal origins of the bentonite deposits at Los Escullos (Almería, Spain). In: Fenoll Hach-Ali, P., Torres-Ruiz, J., Gervilla, F. (Eds.), Current Research in Geology Applied to Ore Deposits, pp. 675-678

Delgado, A., Reyes, E., 1996. Oxygen and hydrogen isotope composition in clay minerals: a potential single-mineral geothermometer. Geochim. Cosmochim. Acta 60, 4285-4294.

Di Battistini, G., Toscani, L., Iaccarinos, S., Villa, I.M., 1987. K/Ar ages and the geological seting of calc-alkaline volcanic rocks from Sierra de Gata, SE Spain. Neues Jahrb. Mineral. 24, 369-383.

Einsele, G., 1986. Interaction between sediments and basalt injections in young Gulf of California-type Spreading Centers. Geol. Rundsch. 75, 197-208.

Fernández-Soler, J.M., 1987. Análisis e interpretación de los materiales volcánicos del Cerro de Los Frailes (Cabo de Gata, Almería). Estud. Geol. 43, 359-366.

Fernández-Soler, J.M., 1992. El volcanismo calco-alcalino de Cabo de Gata (Almería). Estudio volcanológico y petrológico. Ph.D. Thesis, Univ. Granada, Spain.

Fernández-Soler, J.M., 2002. Thermal Effect: Morrón de Mateo outcrops. Geological Seting Memoir. BARRA II Pro ject Report.

Fernández-Soler, J.M., Muñoz, M., 1988. Algunos modelos de facies en el volcanismo de Cabo de Gata: importancia de las emisiones "multi-vent" en una zona calcoalcalina. In: Simposios II Congreso Geol. España. Granada, pp. 397-404.

Guillaume, D., Neaman, A., Cathelineau, M., Mosser-Ruck, R., Peiffert, C., Abdwlmoula, M., Dubessy, J., Villieras, F., Baronenet, A., Michau, N., 2003. Experimental synthesis of chlorite form smectite at $300^{\circ} \mathrm{C}$ in the presence of metallic Fe. Clay Miner. 38, 281-302.

Guillaume, D., Neaman, A., Cathelineau, M., Mosser-Ruck, R., Peiffert, C., Abdelmoula, M., Dubessy, J., Villiêras, F., Michau, N., 2004. Experimental study of the ransformation of smectite at 80 and $300^{\circ} \mathrm{C}$ in the presence of Fe oxides. Clay Miner. 39, 17-34.

Hilgen, F.J., Iaccarino, S., Krijgsman, W., Montanari, A., Raffi, I., Turco, E., Zachariasse, W.J., 2003. The global stratotype section and point (GSSP) of the Tortonian stage (Upper Miocene): a proposal. International Union of Geological Sciences. International Commission on Stratigraphy. Subcommission on Neogene Stratigraphy, $17 \mathrm{pp}$ (unpublished report).

Hoffman, J., Hower, J., 1979. Clay mineral assemblages as low grade metamorphic geothermometers: application to the thrust-faulted disturbed belt of Montana, USA. Society of Economic Paleontologists and Mineralogists. Special Publication 26, pp. 55-79.

Inoue, A., 1985. Chemistry of corrensite: a wend in composition of trioctahedral chlorite/smectite during diagenesis. J. College Arts Sci. Chiba Univ. B 18, 69-82.

Inoue, A., 1987. Conversion of smectite to chlorite by hydrothermal and diagenetic alterations, Hokuroku Kuroko mineralization area, northeast Japan. Proc. Int. Clay Conf., Denver 1985, 158-164.

Inove, A. Utada, M., 1991. Smectite-to-chlorite transformation in thermally metamorphosed volcanoclastic rocks in the Kamikita area, northern Honshu, Japan. Am. Mineral. 76, 628-640.

Inoue, A., Utada, M., Nagata, H., Watanabe, T., 1984. Conversion of trioctahedral smectite to interstratified chlorite/smectite in Pliocene acidic pyroclastic sediments of the Ohyu district, Akita Prefecture, Japan. Clay Sci. 6, 103-116

Kelts, K., 1982. Petrology of hydrothermally metamorphosed sediments at Deep-Sea Drilling Site-477, Southern Guaymas basin rift, Gulf of California. Initial Rep Deep SeaDrilling Project 64, 1123-1136.

I.inares, J., Huertas, Reyes, E., Caballero, E., Barahona, E., Guardiola, J.L., Yáñez, J., Romero, E., Delgado, A., 1993. Investigación de bentonitas como materiales de sellado para almacenamiento de residuos radiactivos de alta actividad. Publicación Técnica ENRESA 01/93.

I.iou, J.G., Seki, Y., Guillemette, R.N., Sakai, H., 1985. Compositions and paragenesis of secondary minerals in the Onikobe geothermal system, Japan. Chem. Geol. $49,1-20$.

Meunier, A., Inoue, A., Beaufort, D., 1991. Chemographic analysis of trioctahedral smectite-to-chlorite conversion series from the Ohyu Caldera, Japan. Clays Clay Miner. 39, 409-415

Newman, A.C.D., Brown, G., 1987. The chemical constitution of clays. In: Newman, A.C.D. (Ed.), Chemistry of Clays and Clay Minerals. Mineralogical Society, London, pp. 1-128. 
Pelayo, M., 2008. Variación de la composición química de las esmectitas del yacimiento de Morrón de Mateo (Cabo de Gata, Almería). Trabajo para la obtención de la Suficiencia Investigadora. Universidad Complutense de Madrid. CIEMAT/DMA/2H001/08.

Pelayo, M., Labajo, M.A., García Romero, E., Pêrez del Villar, L., 2009. Naturaleza de las esmectitas del yacimiento de Morrón de Mateo (Cabo de Gata, Almería) en relación con la roca madre y con los procesos posteriores a la bentonitización: implicaciones analógicas para la barrera de ingeniería de un almacenamiento de residuos radiactivos. Informe Técnico CIEMAT, No. 1174.

Pêrez del Villar, L., Delgado, A., Reyes, E., Pelayo, M., Fernández-Soler, J.M., Cózar, J.S., Tsige, M., Raya, J., 2003. Thermochemically-induced transformations in AIsmectites from Morrón de Mateo: an analogue process of the clayey-barrier behaviour (Cabo de Gata, Almería).BARRA II Project Thermal Effect. Informe Têcnico CIEMAT/DIAE/54450/3/03.

Pêrez del Villar, L., Delgado, A., Reyes, E., Pelayo, M., Fernández-Soler, J.M., Cózar, J.S., Tsige, M., Quejido, A.J., 2005. Thermochemically induced transformations in AIsmectites: a Spanish natural analogue of the bentonite barrier behaviour in a radwaste disposal. Appl. Geochem. 20, 2252-2282.

Reynolds Jr., R.C., 1985. NEWMOD a Computer Program for the Calculation of OneDimensional Diffraction Patterns of Mixed-Layered Clays. R.C. Reynolds, 8 Brook Rd., Hanover, NH 03755.

Robinson, D., Santana de Zamora, A., 1999. The smectite to chlorite transition in the Chipilapa geothermal system, El Salvador. Am. Mineral. 84, 607-619.

Robinson, D., Bevis, R.E., Rowbotham, G., 1993. The characterization of mafic phyllosilicates in low grade metabasalts from eastern North Greenland. Am. Mineral. 78, 377-390.

Robinson, D., Schmidt, S.Th., Santana de Zamora, A., 2002. Reaction pathways and reacion progress for the smectite-to-chlorite transformation: evidence form hydrothermally altered metabasites. J. Metamorph. Geol. 20, 167-174.
Schiffman, P., 1995. Low grade metamorphism of mafic rocks. Rev. Geophys. Supp. 33, 81-86.

Schiffman, P., Fridleifsson, G.O., 1991. The smectite chlorite wansition in drillhole NJ-15, Nesjavellir geothermal field, Iceland: XRD, BSE and electron microprobe investigations. J. Metamorph. Geol. 9, 679-696.

Schiffman, P., Staudigel, H., 1995. The smectite to chlorite transition in a fossil seamount hydrothermal system: the basement complex of La Palma, Canary Islands. J. Metamorph. Geol. 13, 487-498.

Schmidt, S., Robinson, D., 1997. Metamorphic grade and porosity/permeability controls on mafic phyllosilicate distributions in a regional zeolite to greenschist facies transition of the North shore Volcanic Group, Minesota. Geol. Soc. Am. Bull. 109, 683-697.

Schultz, L.G., 1964. Quantitative interpretation of mineralogical composition from X-Ray and chemical data for the Pierre Shale. US Geol. Surv. Prof. Paper 391-C.

Shau, Y.H., Peacor, D.R., 1992. Phyllosilicates in hydrothermally altered basalts from DSDP Hole 504B, Leg 83-a TEM and AEM study. Contrib. Mineral. Petrol. 112, $119-133$.

Velde, B., 1985. Clay Minerals, a Physico-chemical Explanation of Their Occurrence. Developments in Sedimentology, vol. 40. EIsevier, Amsterdam.

Wilson,J., Cressey, G., Cressey, B., Cuadros, J., Ragnarsdottir, KV., Savage, D., Shibata, M., 2006. The effect of iron on montmorillonite stability. (II) Experimental investigation. Geochim. Cosmochim. Acta 70, 323-326.

Zeck, H.P., Whitehouse, M.J., 2002. Pre-eruptional magmatic zircon, Neogene Alborán Volcanic Province, SE Spain. J. Geol. Soc. London 159, 343-346.

Zeck, H.P., Maluski, H., Kristensen, A.B., 2000. Revised geochronology of the Neogene calco-alkaline volcanic suite in Sierra de Gata, Alborán volcanic province, SE Spain. J. Geol. Soc. London 157, 75-81. 